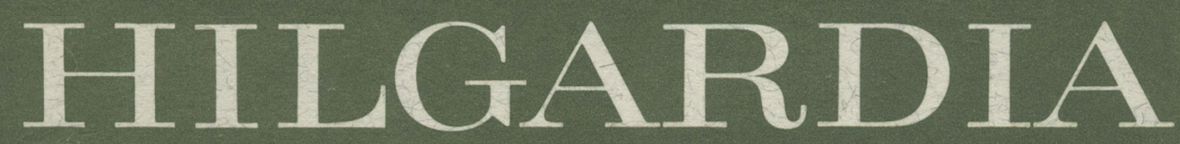

Qjournal of AGRICULTURAL SCIENCE PUBLISHEDBY THE CALIFORNIA AGRICULTURAL EXPERIMENT STATION

Volume 44, Number 2 - August, 1976

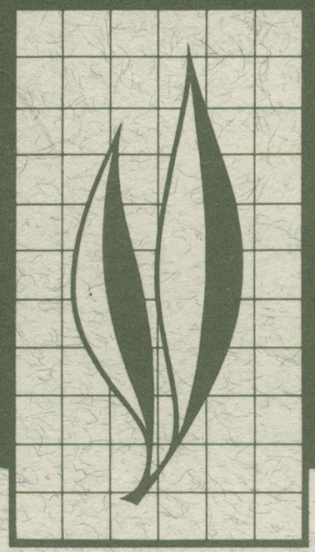

\title{
The Bionomics of
}

Scolothrips sexmaculatus (Pergande)

(Thysanoptera: Thripidae),

an Insect Predator of Spider Mites

Frank E. Gilstrap and Earl R. Oatman 


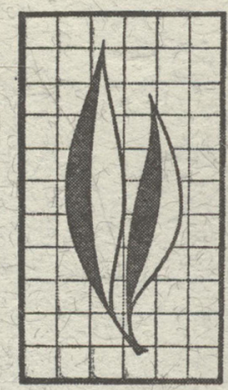

\begin{abstract}
The biology, temperature response, and prey requirements for Scolotbrips sexmaculatus were studied in the laboratory with Tetranychus pacificus as the main prey. At $26.7 \mathrm{C}$ and $50 \%$ relative humidity, the mean life cycle was 8.9 (range: 7.6-10.3) days; egg, 7.2 days; 1st-stage larva, 2.8 days; 2 nd-stage larva, 2.5 days; prepupa, 1.2 days; and pupa, 2.5 days. Male and female immatures developed in the same length of time, but as larvae, killed significantly different mean numbers of prey eggs, 43.0 and 56.0, respectively.

Eggs of $S$. sexmaculatus are inserted into leaf tissue. Larval eclosion lasted a mean $7.6 \mathrm{~min}$, and larvae commenced feeding a mean $40.3 \mathrm{~min}$ after vacating the chorion. No larval preference or nonpreference was noted for any given prey stage.

Imaginal molts lasted a mean $9.1 \mathrm{~min}$, and the new adult commenced feeding after a mean $\mathbf{9 2 . 7} \mathrm{min}$. For adult females, no preference or nonpreference was noted for any prey developmental stage. Mating was unnecessary to induce oviposition, which usually commenced on the 1st imaginal day. Unmated females produced only male progeny. Thus, $S$. sexmaculatus is a facultatively arrhenotokous species.

Larval and adult thrips were behaviorally well adapted to preying on tetranychids which produce copious webbing. Thigmotaxes were evident in all instars, and cannibalism did not occur until prey became scarce.
\end{abstract}

(continued back cover)

\title{
THE AUTHORS:
}

Frank E. Gilstrap is Assistant Professor, Department of Entomology, Texas A\&M University, College Station, Texas.

Earl R. Oatman is Professor of Entomology and Entomologist, Division of Biological Control, Department of Entomology, University of California, Riverside. 


\section{The Bionomics of Scolothrips sexmaculatus (Pergande) (Thysanoptera: Thripidae), an Insect Predator of Spider Mites}

\section{INTRODUCTION}

SPIDER MITES (Acarina: Tetranychidae) are frequent agricultural pests which often cause severe damage to deciduous fruits and nuts, vineyards, and annual crops (van de Vrie et al., 1972). In southern California, the twospotted spider mite, Tetranychus urticae Koch, is usually a serious problem on strawberry, requiring repeated applications of acaricides for its control (Oatman and McMurtry, 1966). Studies by Oatman and McMurtry (1966), Oatman et al. (1967), and Oatman and Voth (1972) revealed that nine species of insects and several species of phytoseiid mites were native predators of $T$. urticae. These studies also revealed that the sixspotted thrips, Scolothrips sexmaculatus (Pergande) (Thysanoptera: Thripidae), was the earliest and most abundant of these predators. A brief life history reported by Bailey (1939) is the only biological information available on $S$. sexmaculatus. The present study of S. sexmaculatus was initiated to further elucidate its biology and prey relationships.

\section{HISTORICAL REVIEW}

Scolothrips sexmaculatus was described as Thrips 6-maculata in a footnote to a paper by Duffey (1892). Pergande (1882) characterized S. sexmaculatus, in part, as being "pale yellow, the head almost white, the thorax darkest, the prothorax often more or less distinctly marked with four small dusky spots and two oblique stripes; frequently the anterior margin of the pterothorax, its disk and a spot near the base of all wings, are also dusky, as is also more or less of the anterior margin of the abdominal segments. The legs are usually pale yellow with only the tip of the tarsi blackish, though now and then a specimen may be met with the apex of the femora dusky and with a pale dusky spot in front and behind, at the base of the anterior and median tibiae. Antennae rather short, either pale dusky, with only the two basal joints pale yellowish, or joints $3-5$ whitish, with only the apex dusky and the last three joints blackish." In 1896, Beach described $T$. pallida (=S. pallidus (Beach)). He characterized $S$. pallidus as having antennal segments 2-8 more or less dusky, but made no reference to other dusky areas on the body. Until recently, the status of both species has been confused. After examining Beach's type speci- 
mens, Hinds (1902) considered S. pallidus to be identical to $S$. sexmaculatus, and he synonomized the former with the latter. Priesner (1950) resurrected S. pallidus and synonomized it with $S$. sexmaculatus (sensu Bailey, 1939). Stannard (1968) reported that Pergande had a mixture of species before him in 1892, a darker species from Califormia and a lighter species from Washington, D.C. Stannard examined Pergande's cotypes in the U.S. National Museum, and designated a lectotype of S. sexmaculatus as the single female specimen on the slide labelled "Thrips 6-naculata Pergande, 120/22, 4363." Thus, according to Stannard, S. sexmaculatus is the darker western species, and the other lighter specimens in the cotype series are $S$. pallidus.

In 1902, Hinds erected Scolothrips, using S. sexmaculatus as the generotype. Priesner (1950) considered $S$. pallidus to be the principal Scolothrips species in California. Two other species of Scolothrips are reported from North America, S. longicornis Priesner and S. hoodi Priesner. Scolothrips hoodi is the only North American species not reported from California (Bailey, 1957; Priesner, 1950), although it is reported from Illinois (Stannard, 1968).

Various morphological aspects of $S$. sexmaculatus are illustrated by Bailey (1939 and 1957), Hinds (1902), Priesner (1950), and Quayle (1912). A key to the species of North America was re- ported by Bailey (1957), and one to the species of Illinois by Stannard (1968), and to the species of the world by Priesner (1950).

Scolothrips sexmaculatus has long been recognized as a specialized predator of spider mites (Fleschner, 1958; Garman, 1924; Garman and Townsend, 1938; Hood and Herrick, 1926; Lamiman, 1935; Leigh, 1963; Lincoln et al., 1953; Lord, 1949; McGregor, 1914; McGregor and McDunough, 1917; McMurtry and Johnson, 1966; McMurtry et al., 1970; Michelbacher, 1959; Michelbacher et al., 1952; Mori, 1967; Muma, 1955 and 1958; Newcomer and Yothers, 1929; Oatman, 1970; Oatman and McMurtry, 1966; Oatman et al., 1967; Pergande, 1882; Quayle, 1912; van den Bosch and Hagen, 1966; Watson, 1918 and 1923; and Whitcomb and Bell, 1964). Based on his studies which revealed that $S$. sexmaculatus had a low fecundity and low food requirements, Bailey (1939) considered it unlikely that this predator was responsible for controlling, or noticeably reducing, spider mite infestations. In contrast to Bailey's views, $S$. sexmaculatus has been reported as causing considerable reductions in spider mite populations on peach (Rice and Jones, 1972), cotton (Lincoln et al., 1953), strawberry (Oatman and McMurtry, 1966; Oatman et al., 1967), and rhubarb (Oatman, 1970).

\section{METHODS AND MATERIALS}

\section{Collection and Maintenance of Stock Colony}

Insectary stocks of S. sexmaculatus originated from six females collected on strawberry plants (Fragaria chiloensis 'Tioga') at the University of California's South Coast Field Station in Orange County. Using the key reported by Bailey (1957), these females were identified as S. sexmaculatus. This determination was made by W. H. Ewart (Thysanoptera systematist, Department of Entomology, University of California, Riverside, CA) and the senior author after examining determined specimens of $S$. sexmaculatus and consulting the literature referred to in the Historical Review. To provide 
food for the stock culture, the Pacific spider mite, Tetranychus pacificus McGregor, was reared as described by Scriven and McMurtry (1971). 'Fresno' strawberry plants used in experiments and for stock culture were grown as described by Bartlett and Katz (1969) in pots in a glasshouse. The plants were fertilized fortnightly with a complete liquid fertilizer.

The stock culture was maintained in the insectary at $26.7 \pm 1 \mathrm{C}, 40-50 \%$ relative humidity, and 12-hr photophase, hereafter referred to as standard conditions. Immatures of $S$. sexmaculatus were held on excised strawberry leaflets which were placed four each on a watersoaked sponge pad $(16 \times 16 \times 1.2 \mathrm{~cm})$ in a stainless steel pan $(19 \times 19 \times 4 \mathrm{~cm})$ (Fig. 1). Such sponges and pans were used wherever plant material was utilized. Each leaflet was ringed with a strip of Cellucotton ${ }^{\circledR}, 10-15 \mathrm{~mm}$ wide, and infested with 100-200 T. pacificus. Twenty-four hr later, 20-25 recently hatched larvae of $S$. sexmaculatus were transferred to each leaflet, where they completed their derelopment on the spider mite females and progeny. Teneral adults of both sexes of S. sexmaculatus were removed twice weekly from - such leaflets and placed on new leaflets prepared as described above. All active stages of S. sexmaculatus and all stages of prey were transferred with the moistened tip of a camel hair brush (size 0000).

The stainless steel pans containing the leaflets were held three each in glass-topped, cloth-backed cages $(30 \times$ $32 \times 41 \mathrm{~cm})$.

\section{Life History Studies}

The life history of $S$. sexmaculatus was obtained at standard conditions. Individual thrips were isolated on leaf dises, $30-\mathrm{mm}$ in diameter, eut from strawberry leaflets. Eight such dises were placed on the perimeter of a sponge pad in a stainless steel pan.
Each disc was ringed with a strip of Cellucotton ${ }^{(1)}, 7-10 \mathrm{~mm}$ wide, providing an arena leaf surface diameter of about $20 \mathrm{~mm}$. Leaf-disc arenas used for larvae of S. sexmaculatus were additionally ringed at the inner edge of the Cellucotton ${ }^{\circledR}$ with a thin barrier of Tree Tanglefoot ${ }^{\circledR}$ to prevent the escape of immatures. The leaf surface inside this barrier constituted an arena of about $16-\mathrm{mm}$ in diameter. Cages fashioned from cross sections of plastic vials were placed over arenas containing adult thrips (Fig. 1). Each cage, $15 \mathrm{~mm}$ high by $47-\mathrm{mm}$ in diameter, had one end covcred with 100-mesh, stainless steel screening. Such leaf-disc arenas and eages were also used in subsequent temperature studies.

Studies requiring constant temperatures were conducted in compact refrigerators, modified as described by Platner et al. (1973). These cabinets maintained temperatures within $\pm 1.1 \mathrm{C}$ of those desired. A 12-hr photophase was maintained in the cabinets, and the relative humidity was held at $50 \pm 5 \%$ by use of sulfuric acid solutions.

To establish the mode of reproduction, 15 females of $S$. sexmaculatus were isolated as mature pupae onto leaf-dise arenas infested with $T$. pacificus. Ten days after imaginal celosion, each female thrips, as yet unmated, was exposed continuously to three 7- to 10 day-old males of $S$. sexmaculatus for 4 days. During the course of the experiment, the thrips were transferred daily to new arenas, and each old arena was held at $26.7 \mathrm{C}$ for larval eclosion. The progeny were reared to adults for sex determination.

Eclosion and posteclosion behavior of 10 1st-stage larvae of S. sexmaculatus were observed at standard conditions on stock culture strawberry leaflets. Each larva was observed continuously from eclosion until completion of the first feeding. To observe imaginal eclosion and posteclosion behavior, 10 

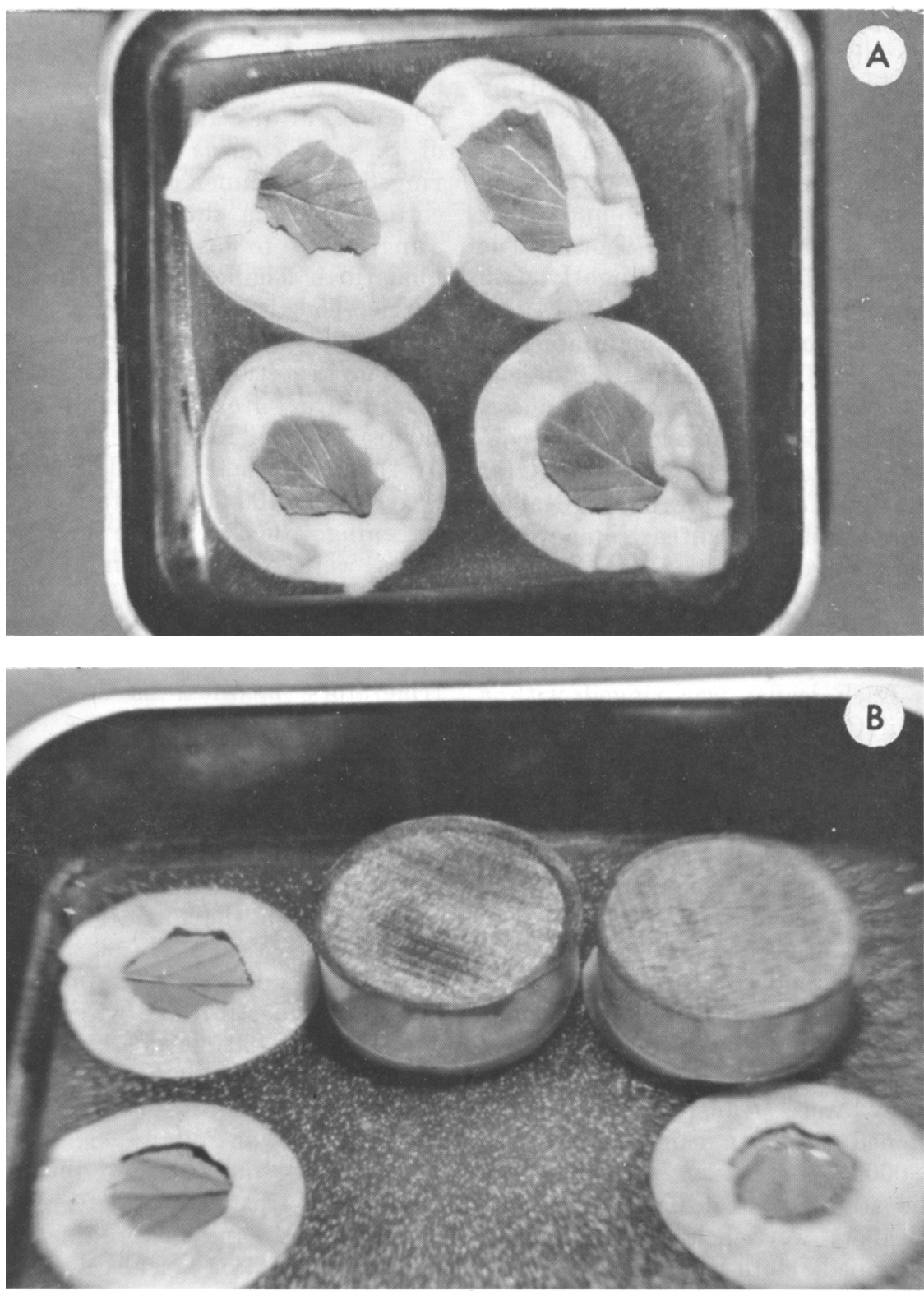

Fig. 1. Experimental methods of rearing and isolating S. sexmaculatus. A) Setup for excised strawberry leaflets used to maintain stock culture in insectary; B) Leaf disc arenas and cages used to isolate individuals.

female pupae of S. sexmaculatus were taken from the stock culture, and each was isolated with three 7- to 10-day-old males on strawberry leaflets infested with $T$. pacificus. Each female was observed continuously at standard condi- tions from the onset of ecdysis until completion of mating. Ten additional females were observed for mating only. Predatory behavior and prey-stage preferences of S. sexmaculatus were investigated, using field-collected castor 
bean (Ricinus communis L.) leaves naturally infested with all stages of the carmine spider mite, Tetranychus cinnabarinus (Boisduval), and of S. sexmaculatus. The excised leaves were placed on a sponge pad in a stainless steel pan and ringed with Cellucotton ${ }^{\circledR}$. Fifteen early 2nd-stage larvae and 15 adults, already on excised leaves, were observed individually for 10 continuous $\mathrm{hr}$ at $26.7 \mathrm{C}$ during normal photophase. When possible, ovipositional behavior was observed during these studies.

The life history of males of S. sexmaculatus was determined at a constant 29.4 C. Leaf-disc arenas were infested for 10-16 hr with 8-10 ovipositioning females of $T$. pacificus. With the webbing kept intact, the mites were then removed, and the number of mite eggs was reduced to 100 . Teneral males of S. sexmaculatus were isolated from the stock culture within $1 \mathrm{hr}$ after eclosion, and placed one each on an arena. Each male was transferred daily to a new arena, and the number of host eggs killed was determined.

\section{Temperature and Life Table Studies}

The influence of several constant temperatures on incubation, developmental time, maximum prey killed, fecundity, longevity, and success of mating was investigated for S. sexmaculatus. Constant temperature cabinets as described above were used in these studies.

Duration of incubation was determined at 40.6, 35.0, 29.4, 26.7, 23.9, and 18.3 C. Ten females of S. sexmaculatus from the stock culture were placed on each of four strawberry leaflets infested with T. pacificus. The female thrips, mites, and mite webbing were removed after $6 \mathrm{hr}$ at $26.7 \mathrm{C}$. The leaflets were then held at a constant temperature and examined every $3 \mathrm{hr}$ for newly hatched larvae. Such procedures were followed for each given temperature. Percent mortality was determined for thrips eggs in leaflets incubated at 23.9 C. A special procedure was used to count the unhatched eggs in these leaflets, as eggs of S. sexmaculatus are inserted into the leaf substrate. Twentyfour hr after hatching ceased, the leaflets were cleared by boiling for $7 \mathrm{~min}$ in a lactophenol solution as described by McBeth et al. (1941), except no stain was used. After clearing, the leaflets were immersed for $48 \mathrm{hr}$ in a lactophenol solution containing $0.05 \%$ acid fuchsin to stain any thrips eggs in the leaflets. The unhatched eggs, which were considerably more darkly stained than hatched eggs, were then counted.

Developmental time and maximum prey killed were determined at 40.6, $35.0,29.4,26.7,23.9,18.3$, and $12.8 \mathrm{C}$ for immatures of S. sexmaculatus. Leafdisc arenas were infested for 10-16 hr with 8-10 ovipositing females of T.pacificus. The mites were then removed, leaving the webbing intact, and the number of mite eggs was reduced to 75 just prior to their exposure to a thrips larva. First-stage thrips larvae less than $1 \mathrm{hr}$ old were taken from the stock culture and placed one each on an arena. Each larva was transferred daily to another such arena until the prepupal molt occurred. Four replicates of eight larvae each were reared concurrently at each of the experimental temperatures, except $26.7 \mathrm{C}$. To detect any change in the stock culture between experiments, a control replicate of eight larvae was reared at $26.7 \mathrm{C}$ each time an experiment was conducted. For all replicates, the stage of development of each thrips was recorded every $8 \mathrm{hr}$. The number of prey eggs killed per 8 hr was determined by subtracting the number of noncollapsed eggs from the number of eggs previously counted.

Fecundity, maximum prey killed, and longevity were determined for females of S. sexmaculatus at 40.6, 35.0, 29.4, and $18.3 \mathrm{C}$. Leaf-disc arenas were prepared as described above for active im- 
matures, except that the number of mite eggs was reduced to 200 . Female thrips were taken from the stock culture as mature pupae, and each was held at $26.7 \mathrm{C}$ on an arena with three 7- to 10-day-old males. The male thrips were removed from each arena with the onset of the first scotophase (12-24 hr) after female imaginal eclosion. Progeny sex ratios were determined for the period $(36-48 \mathrm{hr})$ at $26.7 \mathrm{C}$; for the first 24 $\mathrm{hr}$ at $35.0,29.4$, and $18.3 \mathrm{C}$; and for the second $24 \mathrm{hr}$ at $40.6 \mathrm{C}$. These sex ratios were established by incubating, hatching, and rearing the progeny to adults at $26.7 \mathrm{C}$. The parent female thrips were transferred daily to new arenas.

Eggs laid on every 6th day of exposure to the test temperature were incubated, hatched, and reared to adults at $26.7 \mathrm{C}$ for sex determination. On days when progeny were not hatched and reared to adults, the leaf discs were cleared and stained, and the thrips eggs were counted as described for incubation. The daily number of mite eggs killed per female was determined as described for active immatures. Such experiments were also conducted for groups of females at $23.9 \mathrm{C}$ and $12.8 \mathrm{C}$, except that tests were terminated after 2 and 4 weeks, respectively, precluding determination of longevity for these females.

To collect complete life table data, the sex ratio was determined daily for all progeny produced by 20 females of S. sexmaculatus which were incubated, hatched, reared, and held as adults at $23.9 \mathrm{C}$. The leaf-disc arenas used were prepared as described for females above. Each female was isolated with three 7- to 10-day-old male thrips for 3 days after female imaginal eclosion. The males were then removed. The thrips were transferred daily to new arenas, and the progeny were incubated, hatched, and reared to adults at $23.9 \mathrm{C}$ for sex determination.

The influence of temperature on suc- cess of mating of $S$. sexmaculatus was determined at $40.6,35.0,29.4,26.7,23.9$, 18.3 , and $12.8 \mathrm{C}$. The tests were conducted on leaf-disc arenas infested with ovipositing females of $T$. pacificus. Teneral female thrips isolated from the stock culture as pupae, were each transferred to an arena within $24 \mathrm{hr}$ after eclosion. Simultaneously, a 7- to 10-dayold male thrips was taken from the stock culture and isolated on another arena. The male and female on separate arenas, and a third arena without thrips, were placed in a constant temperature cabinet preset to a given temperature. After $6 \mathrm{hr}$, the male and female thrips were paired on the third arena, and immediately returned to the temperature cabinet. The thrips were removed from the leaf-disc arenas 48 $\mathrm{hr}$ after pairing, and the leaf discs were held at $26.7 \mathrm{C}$ until the thrips eggs therein hatched. The progeny were then reared to adults for sex determination. Successful mating was considered to have occurred when female progeny were produced.

Experimental life tables were constructed for S. sexmaculatus at 40.6 , $35.0,29.4$, and $23.9 \mathrm{C}$, using methods reported by Birch (1948). The intrinsic rate of natural increase $\left(r_{m}\right)$, which is defined as the actual rate of increase of a population under specified constant environmental conditions in which food and space are unlimited, was computed from the life table data using the formula: $\int_{0}^{\propto} e^{-r} m^{x} 1_{x} m_{x} \delta x=1$ where $\mathbf{x}=$ age of the individual in days (age interval); $1_{x}=$ proportion of individuals alive at age $\mathrm{x}$; and $\mathrm{m}_{\mathrm{x}}=$ number of female progeny produced per female in age interval x. Generation time ( $T$ ), defined as the mean length of a generation (birth to weighted mean reproductive age in the adult), was calculated from the formula: $T=\frac{\log _{\mathrm{e}} R_{\mathrm{o}}}{\mathrm{r}_{\mathrm{m}}}$ 
where $R_{0}$ (net reproductive rate) $=$ sum of the $1_{x} m_{x}$ column and represents the mean number of female progeny produced per female in one generation.

\section{Survival at Critical Periods of Prey Availability}

Survival in the absence of prey, the minimum number of prey necessary to support complete immature development, prey capture success, and searching speed are attributes which collectively indicate the potential efficiency of a predator species. These properties were investigated for S. sexmaculatus at standard conditions.

Survival in the absence of food and water was investigated for 1st-stage larvae, 2nd-stage larvae, and females of S. sexmaculatus. The thrips were isolated within $1 \mathrm{hr}$ after hatching or molting and placed in individual glass shell vials, $7 \mathrm{~mm}$ in diameter by $30 \mathrm{~mm}$. The vials were sealed with Parafilm ${ }^{\circledR}$ which was perforated to permit air exchange. The vials and the thrips therein were held at $26.7 \mathrm{C}$ and examined every $3 \mathrm{hr}$ for mortality.

To determine the minimum number of prey kills necessary to support complete immature development, glass culture slides, $7.7 \times 2.5 \mathrm{~cm}$, with a centrally located depression $16 \mathrm{~mm}$ in diameter by $3 \mathrm{~mm}$ deep, were used as isolation arenas. The rims of the de- pressions were lined with a narrow barrier of Tree Tanglefoot ${ }^{\circledR}$. Two methods of limiting prey (eggs of T. pacificus) availability were used. In the first method (I), the total number of mite eggs was limited to $4,6,8,10,15,20$, or 25 . In the second method (II), 1, 2, or 3 mite eggs were provided per $24 \mathrm{hr}$ for as long as the immature thrips fed. Three replicates of 10 larvae each were used in each treatment. A control group of 10 larvae was provided 85 eggs/larva in Method I, and 12 eggs/larva per 24 $\mathrm{hr}$ in Method II. The stage of development was noted every $8 \mathrm{hr}$ until imaginal eclosion or death. Larvae reared by Method I were provided a maximum of eight eggs during the first larval stadium. Larvae reared by Method II were provided the allotted number of prey eggs at the onset of each photophase.

Prey capture success was evaluated for 15 each of 1st-stage larvae, 2ndstage larvae, and females of $S$. sexmaculatus. The thrips were isolated from the stock culture within $1 \mathrm{hr}$ after hatching or molting, and placed in individual glass culture slide arenas described above. Each thrips was starved for $8 \mathrm{hr}$ at standard conditions. After starvation, one egg, larva, or female of T. pacificus was placed in the arena, and the number of contacts between the thrips and the prey, prior to the prey being killed, was recorded.

\section{RESULTS AND DISCUSSION}

\section{Life History Studies}

Larval Eclosion and Posteclosion. The eggs of $S$. sexmaculatus are inserted into plant tissues, as is true of most thrips in the suborder Terebrantia. After a mean incubation period of 7.2 (range: 6.3-8.6) days, the unhatched larvae forced their respective eggs to protrude nearly two-thirds their length from the leaf surface. The larvae then ruptured the chorion transversely, dorsal to the prothorax, and emerged by means of peristaltic contractions of the abdomen. In a mean of 5.0 (range: 3.8-6.3) $\mathrm{min}$, the larvae were free of the chorion except for the terminal one or two abdominal segments. The larvae remained perpendicular to the leaf surface for about $2.5 \mathrm{~min}$, then bent forward, grasped the leaf surface, and pulled their terminal abdominal segments free of the chorion. Eclosion required a mean 7.6 (range: $6.7-8.7$ ) $\mathrm{min}$ after rupture of the chorion. 

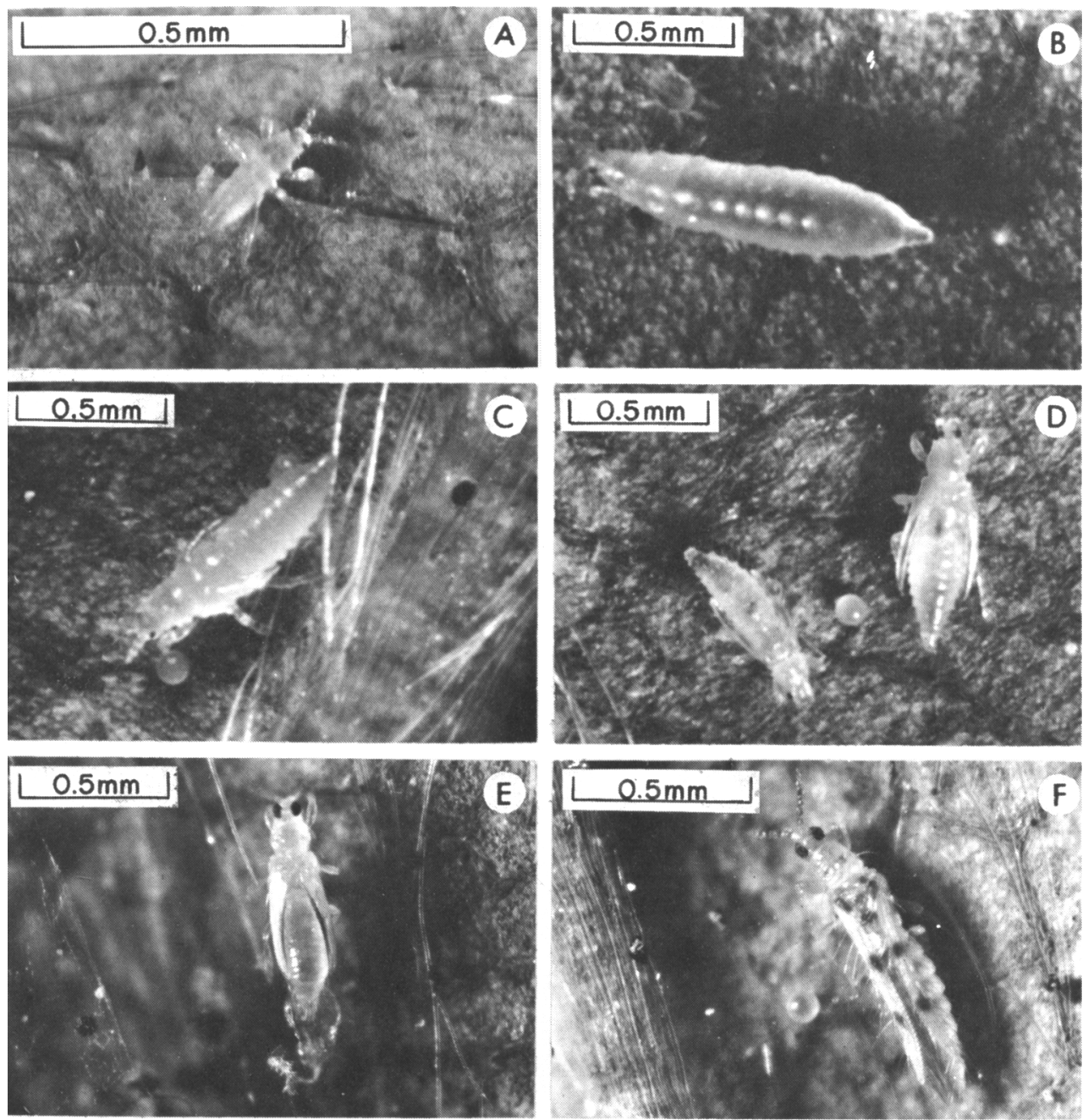

Fig. 2. Life stages of $S$. sexmaculatus. A) recently eclosed 1st-stage larva; B) late 2nd-stage larva; C) prepupa; D) male (left) and female (right) pupae; E) recently eclosed female adult; F) female about 3 days after adult eclosion.

After eclosion the larvae (Fig. 2) were usually quiescent, although they occasionally moved to a new location. The posteclosion period was usually spent in close contact with the spider mite webbing or under a leaf hair. At an average of 40.3 (range: 18.1-79.4) $\mathrm{min}$ after eclosion, the larvae killed their first mite egg. This first feeding activity lasted a mean of 37.3 (range: 16.8 66.6) $\mathrm{min}$, and most of the egg contents were consumed.
Larval Development and Feeding. Although mite eggs were usually utilized as food, 1st-stage larvae fed on all stages and both sexes of spider mite. A mean of 11.2 (range: 6-15) mite eggs was killed by 48 larvae during the mean 2.8 (range: 2.3-3.0) days of 1st-stage larval development. The larvae fed at somewhat regular intervals until 16-2t hr prior to ecdysis, when fecding ceased entirely.

The gut apparently was evacuated 
just prior to molting, as the larvae took on a translucent appearance, but retained a red coloration in the compound eyes. Larval ecdysis was initiated with a transverse rupture of the dorsal integument of the prothorax. The cuticle was shed with peristaltic contractions in the thorax and abdomen. The dorsal integument anterior to the rupture was pulled forward across the vertex and frons, and then was forced posteriorly with the rest of the cuticle.

Within $1 \mathrm{hr}$ after molting, the new 2nd-stage larvae resumed feeding. Forty-eight of these 2nd-stage larvae killed a mean 40.2 (range: 18-68) mite eggs and required 2.5 (range: 2.0-3.3) days for development. The mean total mite eggs killed by both larval stages was 51.1 (range: 29-82).

The gut coloration of thrips larvae usually reflects the prey most recently consumed. Mite eggs caused a tan tint, active stages of $T$. pacificus and $T$. urticae a greenish tint, and summer females of $T$. cinnabarinus an orange-reddish tint.

An observational study of 2nd-stage larvae of $S$. sexmaculatus was conducted on field-collected castor bean leaves naturally infested with all stages of the carmine mite, T. cinnabarinus, and of S. sexmaculatus. Usually the thrips larvae thoroughly searched an area 1 to $1.5 \mathrm{~cm}$ in diameter before moving to another location. The thrips achieved such a change of location by forcing themselves through the mite webbing where it contacted the leaf veins. Thrips larvae pursued active stages of prey only after physical contact, and the pursuit of contacted prey continued for only $2-5 \mathrm{~mm}$.

Once captured, the various prey stages were held by the prothoracic tarsi of the thrips larvae. Active mite stages were usually fed on at a median point between the eyespots. Such prey occasionally continued to move through the webbing after the thrips initiated feeding, but ceased all ambulatory motion after $10-20$ sec.

During these observations, feeding durations of selected prey stages of $T$. cinnabarinus were obtained. These data are summarized in Table 1, where the differences among means were measured using the Student-Newman-Keuls (SNK) procedure as described by Sokal and Rohlf (1969). The number of each prey stage killed probably reflects the relative number of individuals of each stage available, and not a prey-stage preference. This interpretation is based on observations of larval searching behavior. Although not always successful, larvae always attacked the first prey encountered. Except for active deutonymphal prey, at least one individual of each prey category was killed and fed on. Any captured prey stage apparently was acceptable as food. The mean feeding duration by thrips larvae was significantly different for younger eggs (egg contents clear and translucent), compared to those near eclosion (embryo visible with red eyespots). The duration of feeding on successive life stages of prey was usually successively longer. The 15 observed larvae spent an average $70 \%$ of the observational period at rest, $17 \%$ in ambulatory motion, $12 \%$ in feeding, and $1 \%$ in cleaning their legs and antennae.

First- and 2nd-stage larvae of S. sexmaculatus are well adapted behaviorally to accommodate the copious webbing produced by some members of Tetranychidae. When released onto a strawberry leaflet infested with $T$. pacificus, both 1st- and 2nd-stage larvae immediately penetrated the webbing. After gaining access below the webbing, they became less active or ceased motion altogether. Larvae placed on leaflets with an abundance of mite eggs, but without mite webbing, continued to search and usually came to rest only after locating a site where two leaf veins converged, or where leaf hairs 
FEEDING DURATION PER SELECTED PREY STAGE OF T. CINNABARINUS FOR 15 FIELD-COLLECTED, EARLY 2ND-STAGE LARVAE OF S. SEXMACULATUS $S^{\mathrm{a}, \mathbf{b}}$

\begin{tabular}{|c|c|c|c|}
\hline \multicolumn{2}{|l|}{ Prey Stage } & \multicolumn{2}{|c|}{$\begin{array}{l}\text { Feeding Duration } \\
\text { (Min)/Observation }\end{array}$} \\
\hline $\begin{array}{c}\text { State of } \\
\text { Development or Sex }\end{array}$ & $\begin{array}{c}\text { Number } \\
\text { Observations }\end{array}$ & Mean \pm S.E.c & Range \\
\hline \multicolumn{4}{|l|}{ Egg } \\
\hline 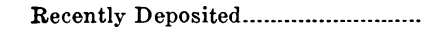 & 92 & $3.8 \pm 0.1 \mathrm{a}$ & $1.6-7.3$ \\
\hline Partially Developed.......................... & 48 & $4.3 \pm 0.2 \mathrm{a}$ & $1.7-8.2$ \\
\hline 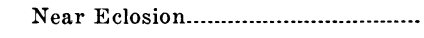 & 29 & $5.6 \pm 0.4 \mathrm{~b}$ & $3.4-12.9$ \\
\hline \multicolumn{4}{|l|}{ Larva } \\
\hline 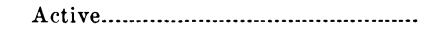 & 17 & $5.4 \pm 0.5 b$ & $3.4-9.3$ \\
\hline Molting & 4 & $8.7 \pm 1.9$ & $5.4-13.8$ \\
\hline \multicolumn{4}{|l|}{ Protonymph } \\
\hline Active........................... & 3 & $10.6 \pm 2.3$ & $7.5-15.6$ \\
\hline Molting & 2 & $13.8 \pm 0.1$ & $13.7-13.8$ \\
\hline \multicolumn{4}{|l|}{ Deutonymph } \\
\hline Active.................................. & 0 & - & - \\
\hline Molting & 1 & 11.3 & - \\
\hline \multicolumn{4}{|l|}{ Adult } \\
\hline 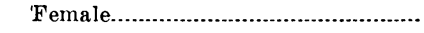 & 6 & $26.1 \pm 10.2$ & $2.8-72.6$ \\
\hline 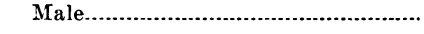 & 1 & 22.4 & - \\
\hline
\end{tabular}

- Arena was a field-collected castor bean leaf naturally infested with all stages of prey mite.

b Larvae were observed individually for 10 continuous hr at standard conditions during the normal photophase (see text).

c Means followed by the same letter on a vertical line are not significantly different at the $1 \%$ level (SNK test).

apparently provided a thigmotactic stimulus.

There were no discernable morphological differences between sexes of either larval stage. Usually, however, the larger, more robust, 2nd-stage larvae (Fig. 2) became female adults.

Postlarval Development. The larval molt to prepupa was similar to that described for the molt from 1st- to 2ndstage larva. Feeding ceased 16-24 hr prior to molting, and the larvae took on a translucent appearance which was retained in the prepupal and pupal stages. Prepupae possessed wing pads which extended just posterior to the metathoracic coxae (Fig. 2). The antennae were oriented anteriorly. The prepupal stage was nonfeeding, but mobile; and, for 48 individuals, lasted 1.2 (range: 1.0-1.6) days. Male prepupae were about one-half to two-thirds the body length of females, and had a narrow or more spinose abdomen.

After the pupal molt, the wing pads extended to about one-half the length of the abdomen, and the antennae were oriented posteriorly along the median dorsal line (Fig. 2). The pupa was also nonfeeding, but mobile; and, for 48 individuals, this stadium lasted 2.5 (range: 1.6-2.6) days. The external morphological features of each sex were as described for prepupae. Total developmental time for active immature stages of 48 individuals was 8.9 (range: 7.6-10.3) days.

Adults. Imaginal eclosion for both sexes occurred at all hours of photophase. Three to $6 \mathrm{hr}$ prior to ecdysis the pupae darkened to a dull tan. The molt was initiated with thoracic and abdominal peristaltic contractions. The head was oriented in an opisthognathous position, and the body was arched, with its apex at the pronotum. A transverse rupture of the pupal cuticle developed at the posterior edge of the prothorax. The dorsal integument anterior to the rupture was pulled for- 
ward across the vertex and frons, and was then forced posteriorly with the rest of the cuticle. The duration of imaginal eclosion was 9.1 (range: $7.5-$ 11.3) min. The translucent-white, newly eclosed adults usually remained at the site of ecdysis for 15-30 min after molting. Wing bristles were initially oriented anteriorly, and were appressed to the wing structure (Fig. 2). As expansion and drying occurred, the bristles became oriented posteriorly. The first prey was usually killed within $1.5 \mathrm{hr}$ after the imaginal molt. The characteristic three dark gray spots (Fig. 2) on each wing became fully visible after 114.6 (range: 75-150) min. Antennal segments II-VIII, parts of the tibia and tarsus of each leg, and two circular areas on the dorsum of the prothorax, developed a dusky-gray coloration 36-48 hr after ecdysis. Each abdominal tergite possessed a distinct tan pigmentation about $48 \mathrm{hr}$ after ecdysis. These transverse bands of pigmentation darkened further with age, becoming amber in individuals 7 days old or older.

Both males and females were observed apparently initiating mating behavior. The male usually first contacted the quiescent female with his antennae 5-10 hr after she completed molting. The male generally made several attempts to orient himself parallel to the body axis of the female. After everting his intromittent organs and gaining the proper alignment with a receptive female, the male extended the tip of his abdomen down to the posteroventral genital opening of the female and engaged her. Copulation occurred with the male to either the right or left of the female. Twenty such pairings lasted an average of 11.9 (range: 8.518.3) min. Disengagement occurred with one or both sexes walking away. It was not determined whether females of $S$. sexmaculatus are polyandrous. Males, however, are polygamous, as one individual mated with three separate females within a period of about $1.5 \mathrm{hr}$.

Mating was not necessary to induce oviposition. Fifteen unmated females produced 10.12 male progeny daily, but no female progeny. After exposure to males, the same females daily produced 0.33 male progeny and 7.48 female progeny. Fifteen control females, emerging in the presence of adult males, produced 1.7 male progeny and 5.1 female progeny during the 1st $24 \mathrm{hr}$ after adult eclosion. Thus, $S$. sexmaculatus is a facultatively arrhenotokous species (sensu Chapman, 1969) which does not have a prolonged preovipositional period.

When searching for ovipositional sites, females moved slowly over the leaf, stopping periodically and apparently testing the leaf with their mouthparts. When an acceptable site was located, the female arched her abdomen slightly and brought the tip of the ovipositor into contact with the leaf. The ovipositor was pushed back along the leaf surface until it apparently encountered a rough spot. The abdomen was then arched very high and forced downward and posteriorly. The ovipositor, with serrated edges, cut into the leaf with short vertical strokes. During the 10-hr observational periods for each of 15 females, oviposition occurred in the interveinal tissue about $90 \%$ (87) of the time, and in the veinal tissues about $10 \%$ (12). Oviposition required significantly longer time in veinal tissue (at the $\mathrm{P}=0.05$ level) than in interveinal tissue, being 9.9 (range: $5.5-$ 17.6) and 7.3 (range: 2.7-29.1) $\mathrm{min}$, respectively. $\Lambda$ s the ovipositor was withdrawn from the leaf, a string of what appeared to be chorion, still attached to the newly inserted egg, trailed out of the ovipositor and remained external to the leaf.

The searching behavior of females of S. sexmaculatus was observed on fieldcollected castor bean leaves naturally 
TABLE 2

FEEDING DURATION PER SELECTED PREY STAGE OF T. CINNABARINUS FOR 15 FIELD-COLLECTED FEMALES OF $S$. $S E X M A C U L A T U S^{\mathrm{a}, \mathrm{b}}$

\begin{tabular}{|c|c|c|c|}
\hline \multicolumn{2}{|l|}{ Prey Stage } & \multicolumn{2}{|c|}{$\begin{array}{l}\text { Feeding Duration } \\
\text { (Min)/Observation }\end{array}$} \\
\hline $\begin{array}{c}\text { State of } \\
\text { Development or Sex }\end{array}$ & $\begin{array}{c}\text { Number of } \\
\text { Observations }\end{array}$ & Mean \pm S.E.c & Range \\
\hline \multicolumn{4}{|l|}{ Egg } \\
\hline 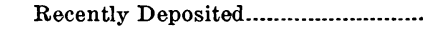 & 212 & $1.2 \pm 0.0 \mathrm{a}$ & $0.6-2.4$ \\
\hline 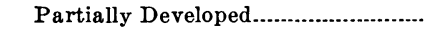 & 73 & $1.4 \pm 0.1 \mathrm{ab}$ & $0.7-2.8$ \\
\hline 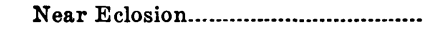 & 39 & $2.1 \pm 0.2 \mathrm{bc}$ & $0.8-6.0$ \\
\hline \multicolumn{4}{|l|}{ Larva } \\
\hline 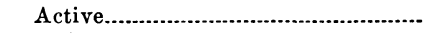 & 63 & $2.2 \pm 0.2 c$ & $0.7-5.4$ \\
\hline 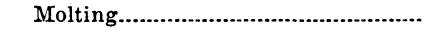 & 25 & $3.1 \pm 0.4 \mathrm{ac}$ & $1.3-7.1$ \\
\hline \multicolumn{4}{|l|}{ Protonymph } \\
\hline 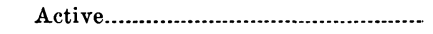 & 12 & $2.3 \pm 0.3 \mathrm{abc}$ & $0.6-3.4$ \\
\hline 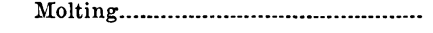 & 11 & $6.2 \pm 0.8 \mathrm{~d}$ & $1.4-9.6$ \\
\hline \multicolumn{4}{|l|}{ Deutonymph } \\
\hline 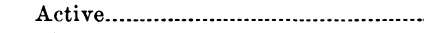 & 12 & $7.5 \pm 1.7 \mathrm{~d}$ & $2.7-23.1$ \\
\hline Molting & 4 & $8.5 \pm 3.2 \mathrm{~d}$ & $2.4-16.8$ \\
\hline \multicolumn{4}{|l|}{ Adult } \\
\hline 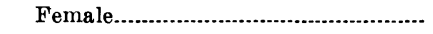 & 14 & $11.8 \pm 1.2 \theta$ & $4.5-20.9$ \\
\hline Male........................................... & 14 & $7.4 \pm 0.9 d$ & $3.0-13.3$ \\
\hline
\end{tabular}

a Arena was a field-collected castor bean leaf naturally infested with all stages of prey mite.

b Females were observed individually for 10 continuous $h r$ at standard conditions during normal photophase (see text).

c Means followed by the same letter on a vertical line are not significantly different at the $1 \%$ level (SNK
test).

infested with all stages of the carmine mite, $T$. cinnabarinus, and of S. sexmaculatus. When searching for prey, the thrips moved slowly through interfering webbing, and usually thoroughly searched a leaf depression about 1-2 $\mathrm{cm}$ in diameter. Adult thrips sometimes passed within $0.5-1.0 \mathrm{~mm}$ of active prey, including those vibrating strands of webbing, but did not seek them out. Physical contact with a prey individual appeared necessary to initiate capture behavior. Once contacted, an active stage was pursued no more than 2-5 $\mathrm{mm}$.

Active stages of prey were usually fed on at a median point between the eyespots. Adult thrips were not carried or pulled by large prey as was true with 1st- and 2nd-stage larvae. The thrips adults used their prothoracic tarsi to hold and manipulate the prey. The contents of mite eggs were usually consumed completely, thus collapsing the chorion walls. Active life stages of prey were usually fed on until they were almost collapsed.

The feeding duration per selected prey of $T$. cinnabarinus is presented in Table 2. The number of each prey lifestage killed probably reflects the relative number of individuals of each prey stage available. Individuals of all prey categories were killed and fed on. Generally, as the size of the prey increased, so did the mean feeding duration. When searching for food, the first prey individual encountered was usually captured and fed on. As with 2nd-stage larvae, there was a significant difference between mean times required for female thrips to consume younger eggs, compared to eggs near eclosion. Also, adult female mites were fed on significantly longer than were males, perhaps due to their larger size. After capture, any host stage was acceptable as food. During 10-hr observational periods for each of 15 females, an average $60 \%$ of the period was spent at rest, $16 \%$ in ambula- 
TABLE 3

INCUBATION TIMES OF S. SEXMACULATUS AT SEVERAL CONSTANT TEMPERATURES, 50\% RELATIVE HUMIDITY, AND 12-HR PHOTOPHASE

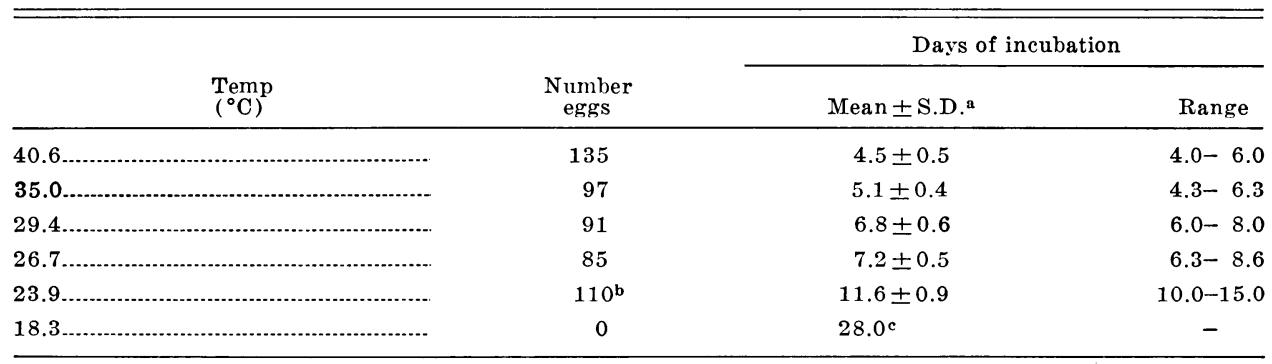

a Each mean is signiflcantly different from each other mean at the $5 \%$ level of significance (SNK test).

b No mortality occurred during incubation.

c No eggs hatched after 28 days of incubation.

tory motion, $13 \%$ in feeding, $9 \%$ in ovipositional activities, and $2 \%$ in cleaning their legs and antennae.

Adults of $S$. sexmaculatus immediately penetrated the mite webbing when released onto a mite-infested strawberry leaf. When webbing was either scant or lacking, the thrips continued walking until they apparently encountered a location that provided a thigmotactic stimulus. Thus, like immature stages, adult thrips are behaviorally adapted to spider mite species which produce copious webbing.

Cannibalism. In the presence of an abundant food supply, cannibalism by S. sexmaculatus was never observed, even at high thrips densities. However, when prey was scarce, the thrips larvae became cannibalistic, an attribute of an efficient predator, as discussed by Nicholson (1933). Bailey (1939) observed S. sexmaculatus to fight among themselves when crowded, and considered them definitely cannibalistic under these conditions. He did not state whether excess food was available when these observations were made.

A quiescent larva, prepupa, or pupa responded with a lateral flick of the abdomen when contacted by another thrips. Larval thrips were never aggressive toward other thrips until prey was scarce. Under these conditions, the larger of two individuals usually pre-

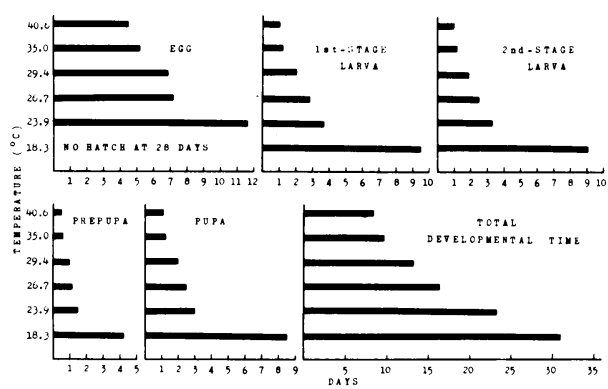

Fig. 3. Comparative developmental times for immature stages of $S$. sexmaculatus incubated or reared at several constant temperatures, with $T$. pacificus as prey.

${ }^{a}$ Larval developmental time only.

vailed and fed on the smaller. Firststage larvae usually cannibalized larvae in the process of hatching, or weak 1ststage larvae. Second-stage larvae cannibalized weak individuals of both larval stages, and larvae during eclosion. Larvae never attacked larvae of similar vigor. Adults only rarely cannibalized immature stages, having usually left an arena prior to total elimination of prey.

\section{Temperature Studies}

Incubation. Eggs of $S$. sexmaculatus developed and hatched at temperatures from $23.9 \mathrm{C}$ to $40.6 \mathrm{C}$ (Table 3, Fig. 3). No eggs hatched after 28 days of incubation at $18.3 \mathrm{C}$. Either $18.3 \mathrm{C}$ was below the thermal threshold for egg 


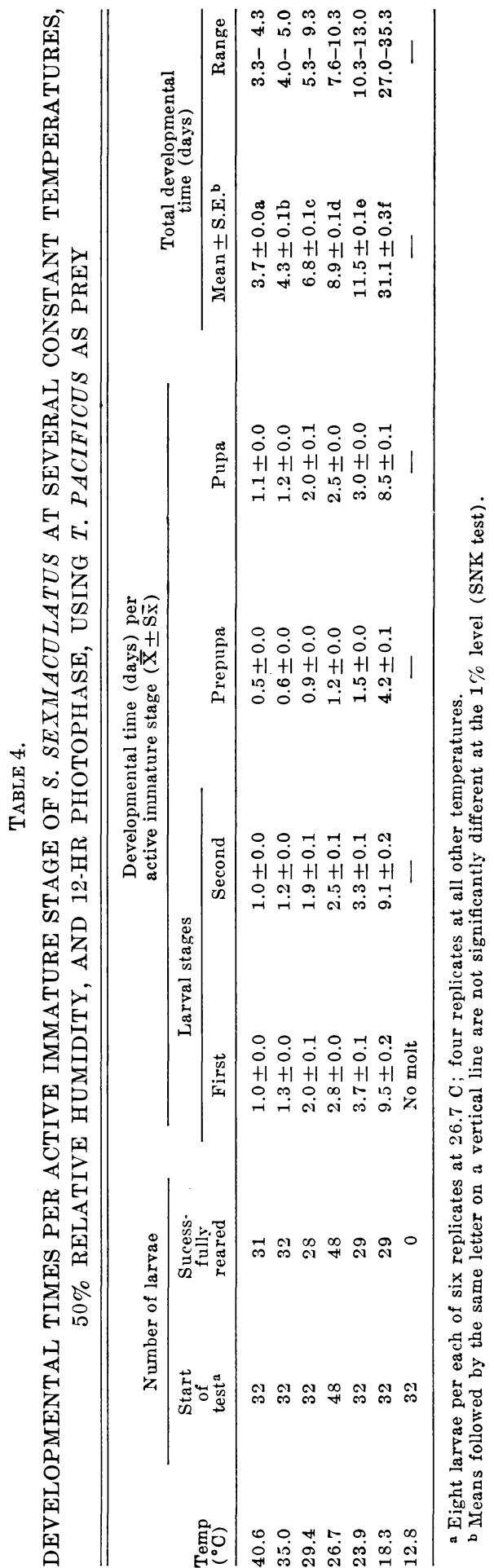

development, or incubation at this temperature exceeded the viability of excised leaves. The mean incubation period at each temperature was significantly different from those at other temperatures. No egg mortality occurred at 23.9 C. Mortality at higher temperatures was not evaluated.

Active Immatures. A set of four replicates of eight larvae each was reared at $12.8,18.3,23.9,29.4,35.0$, and 40.6 C. A control replicate of eight larvae was reared at $26.7 \mathrm{C}$ for each of the temperatures. Analysis of variance conducted on the six control replicates revealed no significant difference in mean developmental times among replicates $(\mathrm{P}=0.001$ level $)$. This lack of difference indicates the temperature response of the stock culture population remained relatively stable during the period of research; therefore, all six replicates were combined to represent a single test temperature in Table 4 . In the absence of thrips larvae, there was no mortality of mite eggs on leaf discs at any of the seven test temperatures. Thus, all mite egg mortality on the test leaf dises could be attributed to thrips feeding.

Active immatures of S. sexmaculatus developed from newly hatched larvae to adults at 18.3 to $40.6 \mathrm{C}$ (Table 4 , Fig $3)$. The mortality indicated in Table 4 was not caused by temperature, but by entanglement in the Tree Tanglefoot ${ }^{(B)}$ barrier during larval movement. Excessive larval movement may have occurred when the spider mite webbing was too scanty to provide a thigmotactic stimulus. Without such a stimulus, the larvae are more active, as discussed earlier. The prepupal stage was the shortest developmental stage at each temperature, being about one-half that for each of the other three active stages. Total developmental time at each temperature was significantly different from that at the other temperatures. At $18.3 \mathrm{C}$, total developmental time for 


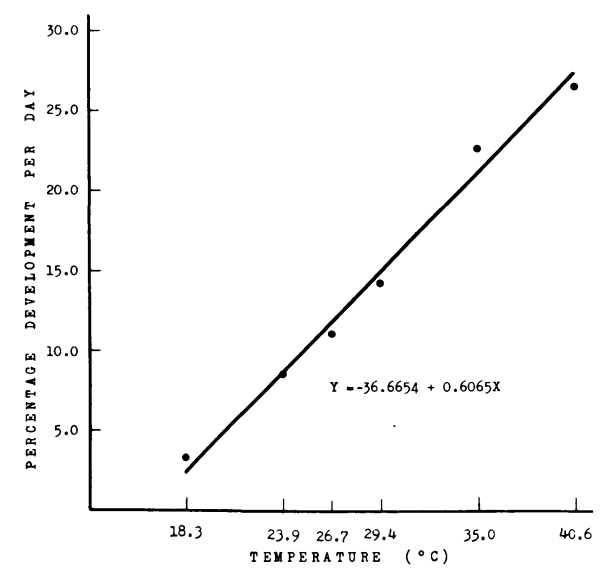

Fig. 4. The relationship between temperature and rate of development of females of $S$. sexmaculatus from hatching to adult eclosion, with $T$. pacificus as prey.

active stages was more than twice that at $23.9 \mathrm{C}$, and no development occurred at $12.8 \mathrm{C}$. Larvae held at $12.8 \mathrm{C}$ never molted to the 2nd-stage, but remained alive for 59.1 (range: 10-103) days.

When percent development per day was plotted against temperature and a regression analysis made, a linear relationship was found to be significant ( $\mathrm{P}=0.001$ level) for both sexes of $S$. sexmaculatus (Figs. 4 and 5). Correlation coefficients for female and male data were 0.994 and 0.993 , respectively. The lower thermal developmental limit was between 12.8 and $18.3 \mathrm{C}$ for both sexes. The estimated lower limit, obtained by solving the regression equations for $\mathrm{Y}=\mathrm{O}$, was $15.8 \mathrm{C}$ for females and 15.7 $\mathrm{C}$ for males. These values are only approximations and are subject to the hazards of extrapolation.

There was no significant difference in developmental times between males and females exposed to the same temperature. Females, after imaginal eclosion, were isolated with two males. All such females, at each respective temperature, mated and produced progeny. Thus, none of the developmental temperatures in the present study pre-

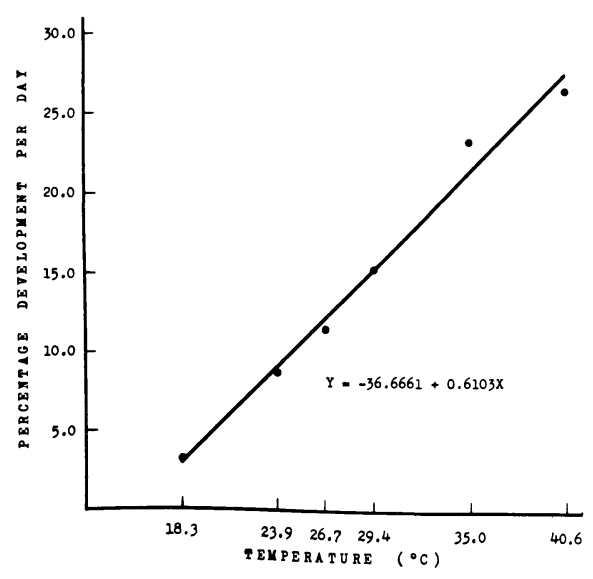

Fig. 5. The relationship between temperature and rate of development of males of $S$. sexmaculatus from hatching to adult eclosion, with $T$. pacificus as prey.

vented development of reproductively functional females.

Generally, the mean number of mite eggs killed by 1st-stage larvae remained similar for each sex at all temperatures (Table 5). At only two temperatures was there significant difference between sexes in the number of eggs killed. Second-stage male larvae killed similar numbers of mite eggs at all temperatures. Temperature had no effect on the number of mite eggs killed by 2nd-stage male or female larvae. However, males killed about two-thirds as many mite eggs as did females.

The significant differences noted between sexes of 2nd-stage larvae remained when the numbers of mite eggs killed by larvae were summed (Table $6)$. There were no significant differences between the numbers of eggs killed by males at the several temperatures. Although total numbers of eggs killed by female larvae at each temperature were significantly different in several cases, there was no apparent trend of increase or decrease in total numbers of mite eggs killed as temperature was increased or decreased. Although they never molted, 1st-stage larvae held at 
TABLE 5

NUMBER OF EGGS OF T. PACIFICUS KILLED BŸ MALE AND FEMALE LARVAE OF $S$. SEXMACULATUS REARED AT DIFFERENT CONSTANT TEMPERATURES, $50 \%$ RELATIVE HUMIDITY, AND 12-HR PHOTOPHASE

\begin{tabular}{|c|c|c|c|c|c|c|}
\hline \multirow{3}{*}{$\underset{\left({ }^{\circ} \mathrm{C}\right)}{\text { Temp }}$} & \multirow{2}{*}{\multicolumn{2}{|c|}{$\begin{array}{c}\text { Number } \\
\text { of } \\
\text { larvae }\end{array}$}} & \multicolumn{4}{|c|}{ Number of eggs killed $(\overline{\bar{X}} \pm S \bar{x})^{b}$} \\
\hline & & & \multicolumn{2}{|c|}{ 1st-Stage larvae } & \multicolumn{2}{|c|}{ 2nd-Stage larvae } \\
\hline & 'Female & Male & Female & Male & Female & Male \\
\hline 40.6 & 23 & 8 & $11.0 \pm 0.5$ & $10.0 \pm 0.9 \mathrm{~ns}$ & $45.1 \pm 1.1$ & $32.3 \pm 3.3 * * *$ \\
\hline 35.0 & 17 & 15 & $10.6 \pm 0.5$ & $10.1 \pm 0.5 \mathrm{~ns}$ & $47.3 \pm 1.2$ & $31.8 \pm 1.6^{* * *}$ \\
\hline 29.4 & 19 & 9 & $12.7 \pm 0.5$ & $10.8 \pm 0.6^{*}$ & $51.2 \pm 2.3$ & $27.8 \pm 2.1 * * *$ \\
\hline 26.7 & 31 & 17 & $11.7 \pm 0.3$ & $10.4 \pm 0.5^{*}$ & $44.3 \pm 1.4$ & $32.8 \pm 2.3 * * *$ \\
\hline 23.9 & 22 & 7 & $12.9 \pm 0.7$ & $10.9 \pm 0.6 \mathrm{~ns}$ & $55.0 \pm 1.7$ & $37.9 \pm 2.0$ *** \\
\hline 18.3 & 18 & 11 & $11.2 \pm 0.5$ & $12.3 \pm 0.6 \mathrm{~ns}$ & $44.6 \pm 2.3$ & $34.7 \pm 2.4^{* * *}$ \\
\hline
\end{tabular}

a Sex determined upon emergence of the adults.

b Differences between males and females at the same temperature and stage of development are: *significant at the $\mathrm{P}=0.05$ level, $* * *$ significant at the $\mathrm{P}=0.001$ level, $\mathrm{ns}$, not significant at $\mathrm{P}=0.05$.

TABLE 6

COMPARISON OF THE TOTAL NUMBER OF EGGS OF T. PACIFICUS KILLED BY MALE AND FEMALE LARVAE ${ }^{a}$ OF $S$. SEXMACULATUS REARED AT DIFFERENT CONSTANT TEMPERATURES, 50\% RELATIVE HUMIDITY, AND 12-HR PHOTOPHASE

\begin{tabular}{|c|c|c|c|c|c|c|}
\hline \multirow{3}{*}{$\begin{array}{l}\text { Temp } \\
\left({ }^{\circ} \mathrm{C}\right)\end{array}$} & \multirow{2}{*}{\multicolumn{2}{|c|}{$\begin{array}{c}\text { Number } \\
\text { of larvae }\end{array}$}} & \multicolumn{4}{|c|}{ Number of eggs killed } \\
\hline & & & \multicolumn{2}{|c|}{ Mean \pm S.E.b,c } & \multicolumn{2}{|c|}{ Range } \\
\hline & Female & Male & Female & Male & Female & Male \\
\hline 40.6 & 23 & 8 & $56.1 \pm 1.1 \mathrm{abc}$ & $42.3 \pm 3.7 \mathrm{a} * * *$ & $46-65$ & $35-62$ \\
\hline 35.0 & 17 & 15 & $57.9 \pm 1.3 \mathrm{abcd}$ & $41.9 \pm 1.7 a^{* * *}$ & $51-68$ & $33-54$ \\
\hline 29.4 & 19 & 9 & $63.9 \pm 2.2 \mathrm{ade}$ & $38.6 \pm 2.6 a^{* * *}$ & $50-94$ & $29-55$ \\
\hline 26.7 & 31 & 17 & $56.0 \pm 1.6 \mathrm{ab}$ & $43.2 \pm 2.1 \mathrm{a} * \star *$ & $43-82$ & $29-55$ \\
\hline 23.9 & 22 & 7 & $68.0 \pm 1.5 \mathrm{e}$ & $48.7 \pm 1.8 \mathrm{a} * \star *$ & $56-83$ & $43-55$ \\
\hline 18.3 & 18 & 11 & $55.8 \pm 2.7 \mathrm{a}$ & $47.0 \pm 2.3 a^{*}$ & $34-70$ & $37-60$ \\
\hline
\end{tabular}

a Sex was determined upon emergence of the adults. test).

b Means followed by the same letter on a vertical line are not significantly different at the $1 \%$ level (SNK

c Differences between males and females at the same temperature are: * significantly different at $\mathbf{P}=0.05$ level; *** significantly different at $\mathrm{P}=0.001$.

12.8 C killed 22.13 (range: 2-48) mite eggs prior to death.

Adults. The influence of temperature on fecundity, sex ratio, and mating success was determined for S. sexmaculatus at $12.8,18.3,23.9,29.4,35.0$, and 40.6 C. Longevity was determined at each temperature except $12.8 \mathrm{C}$. Twenty females were studied at each temperature in all tests except the one involving mating success, and the test at $29.4 \mathrm{C}$, in which replicates of seven females were used as controls for each of the other five temperatures. Analysis of variance revealed no significant differences
(0.1\% level) among data collected for the five replicates at $29.4 \mathrm{C}$. Thus, the data for this temperature were combined, and represent 35 females (Table 7).

Females used in each of the temperature regimes were kept in the presence of three males at $26.7 \mathrm{C}$ for the first $36-48 \mathrm{hr}$ after adult eclosion, and then were isolated at a given temperature. Each female mated and began oviposition within the first $24 \mathrm{hr}$ after adult eclosion, producing at least two female progeny during the period at $26.7 \mathrm{C}$. There was no significant difference be- 


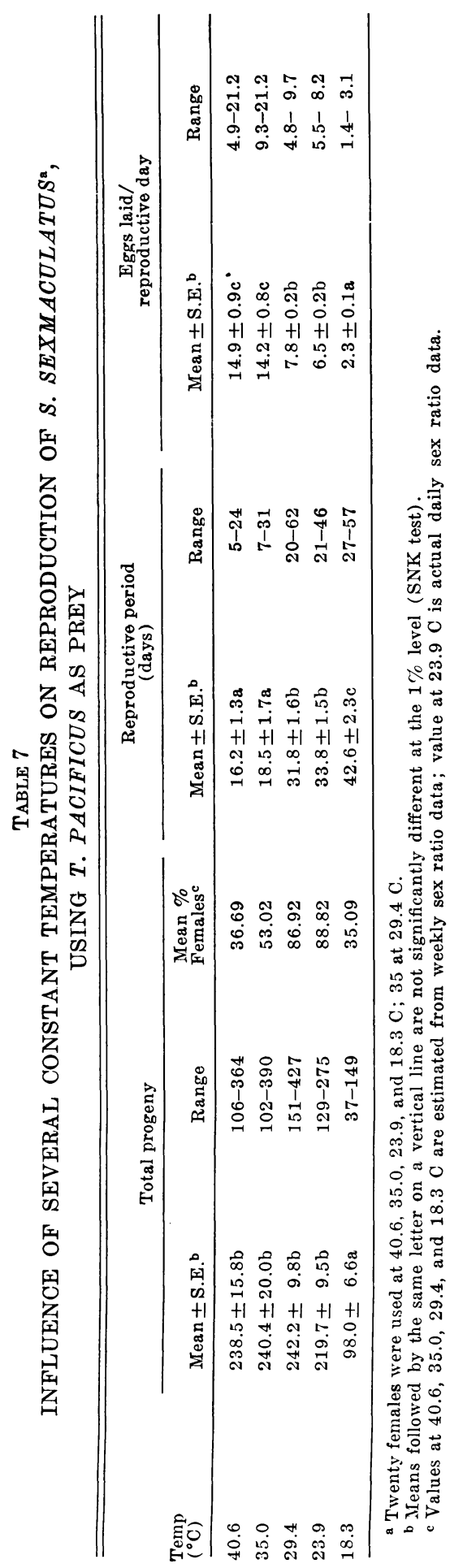

tween 40.6 and $35.0 \mathrm{C}$, and between 29.4 and $23.9 \mathrm{C}$, for the mean reproductive period and mean eggs laid per reproductive day, respectively (Table 7 ). However, for mean total progeny, only the number of progeny produced at $18.3 \mathrm{C}$ was significantly different from the numbers produced at the other temperatures. Comparison of the data for 23.9-40.6 C revealed that the greater rate of progeny production at the two higher temperatures was offset by a longer reproductive period at the two lower temperatures. The variability of total progeny production within each temperature was not very high, as coefficients of variation ranged from a low of $17 \%$ at $23.9 \quad \mathrm{C}$ to a high of $37 \%$ at $35.0 \mathrm{C}$. The mean daily fecundity reached its highest value early in the life of the parent female (Fig. 6). These values were 25.25 eggs at $40.6 \mathrm{C}, 20.85$ at $35.0 \mathrm{C}, 11.17$ at 29.4 $\mathrm{C}, 9.30$ at $23.9 \mathrm{C}$, and 3.85 at $18.3 \mathrm{C}$. The percentage of females in the total progeny increased progressively from 36.7 to 88.8 as the temperature decreased from 40.6 to $23.9 \mathrm{C}$. At each temperature, as the parent females aged, the sex ratio tended to favor males. Although the reproductive period was longest at $18.3 \mathrm{C}$, this temperature was least favorable to increase in thrips numbers, as reflected by the low percentage of females and low, mean total number of progeny produced.

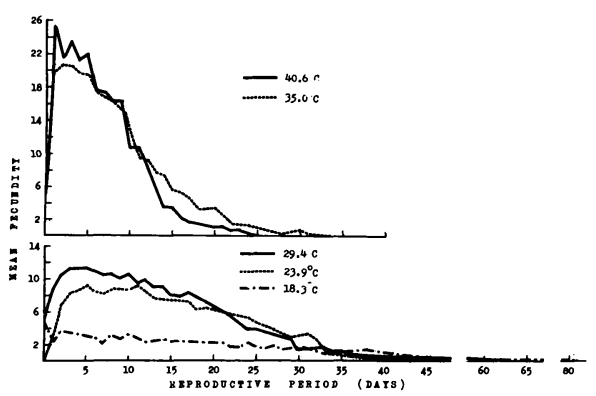

Fig. 6. Mean daily fecundity of S. sexmaculatus at several constant temperatures, with $T$. pacificus as prey. 
TABLE 8

INFLUENCE OF SEVERAL CONSTANT TEMPERATURES ON LONGEVITY OF FEMALES OF S. SEXMACULATUSa, USING T. PACIFICUS AS PREY

\begin{tabular}{|c|c|c|c|}
\hline \multirow{2}{*}{$\begin{array}{l}\left({ }^{\circ} \mathrm{C}\right) \\
\text { Temp }\end{array}$} & \multicolumn{2}{|c|}{ Longevity (days) } & \multirow{2}{*}{$\begin{array}{c}\text { Days until } \\
50 \% \\
\text { mortality }\end{array}$} \\
\hline & Mean \pm S.E.b & Range & \\
\hline 40.6 & $21.5 \pm 1.5 \mathrm{a}$ & $6-33$ & 22 \\
\hline 35.0 & $30.6 \pm 1.9 \mathrm{a}$ & $19-52$ & 29 \\
\hline 29.4 & $46.2 \pm 1.9 \mathrm{~b}$ & $29-69$ & 46 \\
\hline 23.9 & $49.0 \pm 2.6 \mathrm{~b}$ & $28-78$ & 48 \\
\hline 18.3 & $74.3 \pm 5.4 c$ & $31-144$ & 79 \\
\hline
\end{tabular}

a Twenty females were used at $40.6,35.023 .9$, and $18.3 \mathrm{C} ; 35$ at $29.4 \mathrm{C}$.

b Means followed by the same letter on a vertical line are not significantly different at the $1 \%$ level (SNK test).

Bailey (1939) reported a low fecundity for S. sexmaculatus, each female producing only four or five larvae. This is in marked contrast with results from the present study, in which mean daily fecundities at 23.9, 29.4, 35.0, and 40.6 $\mathrm{C}$ exceeded the total fecundity reported by Bailey. Unfortunately, Bailey did not describe the conditions for his observations.

Twenty females held at $12.8 \mathrm{C}$ produced a total of 38 males and 2 females during 4 weeks of testing. All 20 parent females were fertile at exposure to the test temperature. This was evidenced by their production of female progeny during $24 \mathrm{hr}$ at $26.7 \mathrm{C}$. As the two female progeny developed from eggs laid during the first $24 \mathrm{hr}$ at $12.8 \mathrm{C}$, the parent females probably laid those two eggs immediately after exposure to the test temperature. Thus, fertile females apparently can oviposit but not fertilize eggs at $12.8 \mathrm{C}$.

A multiple comparison of means revealed that mean survival times were not significantly different between 40.6 and $35.0 \mathrm{C}$, and between 29.4 and 23.9 C (Table 8). This trend was also present at the same temperatures for the number of days required for $50 \%$ mortality. Reduction of temperature generally resulted in a progressive increase in the rate of survival. Survivorship curves (Fig. 7) are similar to the curves of physiological longevity re- ported by Deevey (1942), Clark and Rockstein (1964), and others. The only exception is at $18.4 \mathrm{C}$.

Male and female thrips individually reared through adult eclosion at $26.7 \mathrm{C}$, successfully mated at 18.3 to $40.6 \mathrm{C}$, as evidenced by the production of female progeny. Females paired with males at $12.8 \mathrm{C}$ produced only male progeny. Thus, the lower thermal limit for mating is between 12.8 and $18.3 \mathrm{C}$.

There were no significant differences in the total numbers of mite eggs killed during the reproductive periods at 40.6 , 35.0, and 29.4 C (Table 9). This was true despite mean differences of about $30 \mathrm{eggs}$ when the data for mite eggs killed per reproductive day are compared at the same three temperatures. The peak mean numbers of eggs killed per day (Fig. 8) were 143.60 at $40.6,111.95$ at $35.0,64.83$ at $29.4,62.30$ at 23.9 , and

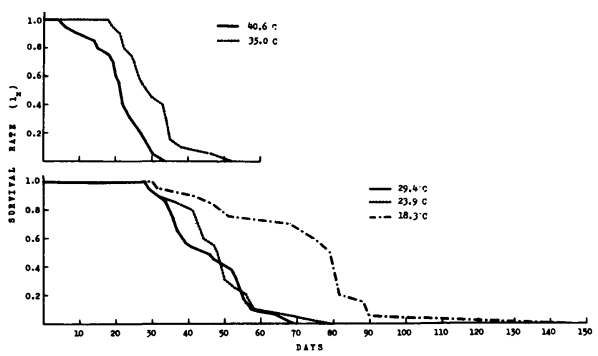

Fig. 7. Survivorship curves for females of S. sexmaculatus at several constant temperatures (based on cohorts of 20 individuals at 18.3, 23.9, 35.0, and $40.6 \mathrm{C}$; and 35 at $29.4 \mathrm{C}$ ), with $T$. pacificus as prey. 


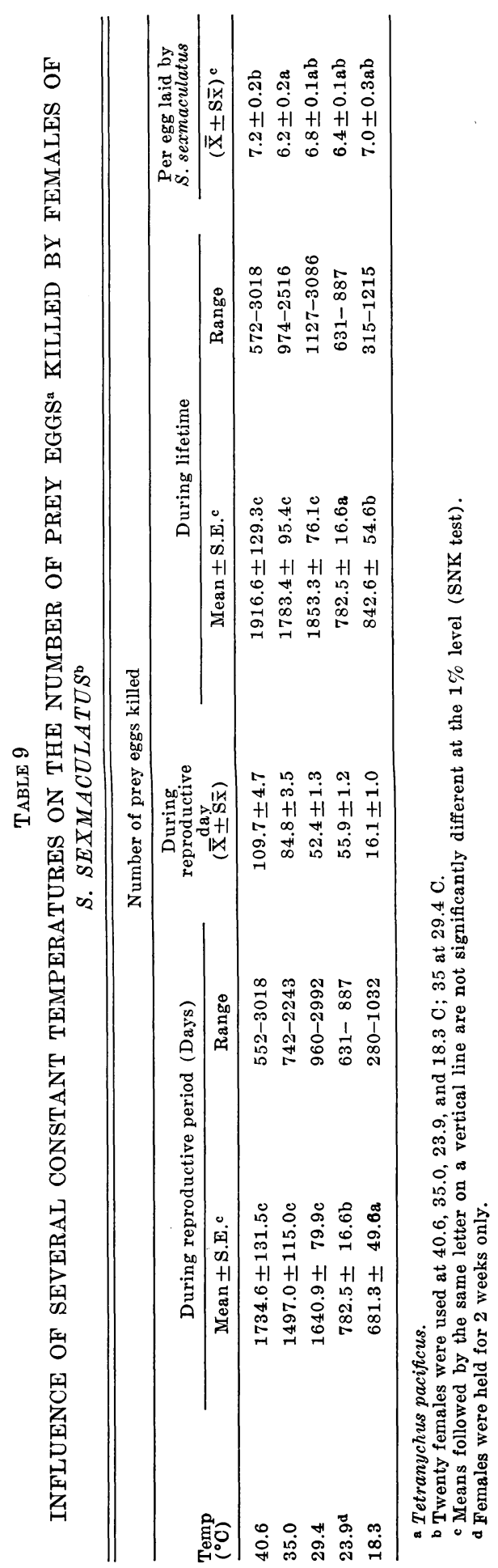

22.40 at 18.3 C. Females used for the $23.9 \mathrm{C}$ regime were held only for the first 2 weeks after adult eclosion. As was true for all other attributes measured at $18.3 \mathrm{C}$, the mean number of eggs killed per reproductive period, per reproductive day, and per lifetime, and the peak daily number of prey killed, were considerably lower at $18.3 \mathrm{C}$ than at any other temperature.

At the five temperature regimes, representing a range of $21.3 \mathrm{C}$, the fecundity per number of prey killed remained nearly constant (Table 9 ). The relationship between temperature and daily fecundity, and between temperature and daily numbers of prey killed, paralleled each other closely.

Prey utilization and longevity for males of S. sexmaculatus were determined at $29.4 \mathrm{C}$. As was true for females, males killed more prey soon after

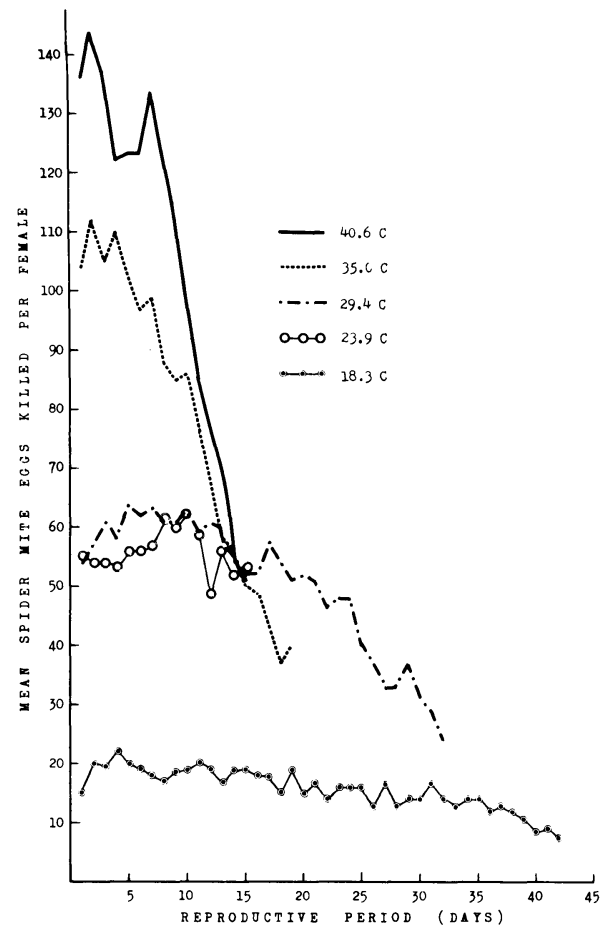

Fig. 8. Mean daily number of eggs of $T$. pacificus killed by females of $S$. sexmaculatus at several constant temperatures. 
TABLE 10

EFFECT OF CONSTANT TEMPERATURES, 50\% RELATIVE HUMIDITY, AND 12-HR PHOTOPHASE ON SEVERAL POPULATION GROWTH STATISTICS OF S. SEXMACULATUS, USING T. PACIFICUS AS PREY

\begin{tabular}{lccccc}
\hline \hline $\begin{array}{c}\text { Mean total } \\
\text { progeny } \\
\left({ }^{\circ} \mathrm{C}\right)\end{array}$ & $\begin{array}{c}\text { Gross repro- } \\
\text { ductive rate } \\
\text { (GRR) } \\
\text { (female pro- } \\
\text { female) }\end{array}$ & $\begin{array}{c}\text { Net } \\
\text { productive } \\
\text { rate (Ro) } \\
\text { (female pro- } \\
\text { geny/female) }\end{array}$ & $\begin{array}{c}\text { Mean gener- } \\
\text { ation time } \\
\text { (T) }\end{array}$ & $\begin{array}{c}\text { Intrinsic } \\
\text { (days) }\end{array}$ & $\begin{array}{c}\text { nate } \\
\text { increase (r) }\end{array}$ \\
\hline 40.6 & 238.5 & 87.50 & 86.53 & 12.39 & 0.360 \\
35.0 & 240.4 & 127.47 & 127.33 & 15.94 & 0.304 \\
29.4 & 242.2 & 210.51 & 206.51 & 22.97 & 0.232 \\
23.9 & 219.7 & 195.13 & 192.07 & 33.92 & 0.155 \\
\hline
\end{tabular}

adult eclosion than they did during the latter part of their lives, reaching a peak 16.70 spider mite eggs on the 2 nd day. Males killed only about one-quarter as many mite eggs daily as did females at the same temperature, $12.3 \pm$ 0.5 and $52.4 \pm 1.3$ eggs, respectively. The mean longevity for males was about one-third longer than that for females, being 60.0 (range: 43-80) days and 46.2 \pm 1.9 (range: 29-69) days, respectively.

Results from the present study indicate S. sexmaculatus kills fairly large numbers of prey when excess prey are available. This finding contrasts markedly with Bailey's (1939) conclusions that $S$. sexmaculatus feed only infrequently, and kill relatively few prey.

\section{Effect of Temperature on Population Growth}

The "reproductive rate" is occasionally referred to as representing the capacity of a given species to increase in numbers. However, without considering the death or survival rate of the progeny, no inference can be made about the innate capacity for population growth (Anderwartha and Birch, 1954). The present study of $S$. sexmaculatus provided information on fecundity, longevity, and speed of development as influenced by temperature. Data for each of these provide useful information, but the "intrinsic rate of natural increase $\left(r_{m}\right)$," is the statistic which summarizes the collective effect of those

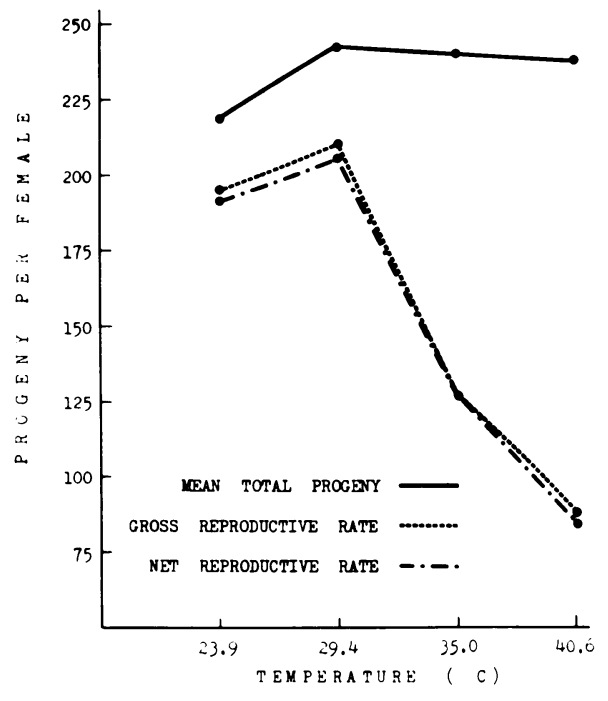

Fig. 9. Mean total progeny, gross reproductive rate, and net reproductive rate of $S$. sexmaculatus at several constant temperatures, with $T$. pacificus as prey.

functions on population increase. Additionally, the statistic $r_{m}$ can be used as a bioclimatic index of population growth (Bursell, 1964; Messenger, 1964).

To calculate $r_{m}$ values for $S$. sexmaculatus, several assumptions were necessary for data at 29.4, 35.0, and $40.6 \mathrm{C}$. The daily sex ratio of progeny and the survival rate of the egg stage were determined experimentally only at 23.9 C. For the purposes of calculation, the sex ratio of progeny from parent females held for the first 2 days at 29.4, 
35.0, and $40.6 \mathrm{C}$ was assumed to be the same as that obtained at the $23.9 \mathrm{C}$ regime. This was necessary because females at the higher three temperatures were held at $26.7 \mathrm{C}$ for the first 36-48 $\mathrm{hr}$ of adult life; thus, no progeny sex ratio data were available at test temperatures for that period. Progeny sex ratios at $29.4,35.0$, and $40.6 \mathrm{C}$ were obtained on the first day of exposure of the parent female at the test temperature, and on each 7 th day thereafter. These latter data were fitted to a curve (2nd order, least squares fit), and the daily numbers of female progeny produced $\left(m_{x}\right)$ at the latter temperatures were derived from the respective curves.

Statistics calculated from life tables are summarized in Table 10. The influence of temperature on the mean total progeny, the gross reproductive rate (GRR), and the net reproductive rate $\left(R_{0}\right)$ are shown in Fig. 9. Each statistic reached a maximum at $29.4 \mathrm{C}$. At the two higher temperatures, the large difference between the mean total progeny and the $R_{0}$ is also reflected in the mean percent females (Table 7). Percent females was lowest at $40.6 \mathrm{C}$, and highest at $29.4 \mathrm{C}$, and the same was true for the $R_{0}$. All measurements of reproductive power were maximal at 29.4 C (Fig. 9).

The curves for GRR and $R_{0}$ were similar at all four temperatures. This was a function of the high survivorship value for parent females during the reproductive period. These values of GRR and $R_{0}$ were almost identical at $35.0 \mathrm{C}$. The mean generation time $(\mathrm{T})$ was inversely related to temperature (Table 10).

For S. sexmaculatus, the lowest percentage of female progeny was produced at $40.6 \mathrm{C}$ (Table 7), and the total numbers of progeny produced at all four temperatures were similar. The reproductive period and survival rate were greatest at $23.9 \mathrm{C}$ (Tables 7 and 8 ), and the total progeny pro-

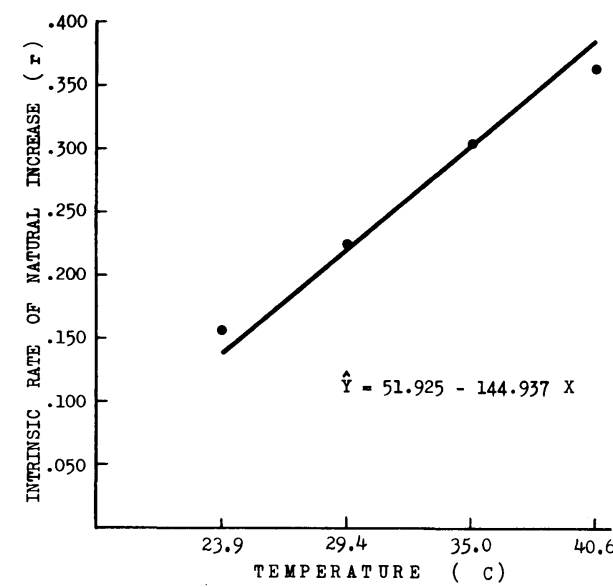

Fig. 10. The effect of several constant temperatures on the intrinsic rate of natural increase of S. scxmaculatus, with $T$. pacificus as prey.

duced, GRR, and $R_{0}$ were maximal at 29.4 C (Table 10). As discussed earlier, individual statistics used to derive $r_{m}$ each give an incomplete, occasionally misleading, conception of the ability of a species population to increase. The complete impact of temperature on population growth is embodied in the statistic $r_{m}$. The values obtained for $r_{m}$ for $S$. sexmaculatus were directly related to, and highly correlated $(\mathrm{r}=$ 0.997) with temperature (Table 10, Fig. 10). Although no optimal temperature was determined, a population of S. sexmaculatus evidently can persist and increase at temperatures ranging at least from 23.9 to $40.6 \mathrm{C}$.

Laing (1968, 1969a, 1969b) reported intrinsic rates of natural increase for two phytoseiid predators, Metaseiulus occidentalis (Nesbitt) and Phytoseiulus persimilis Athias-Henriot, and for a spider mite prey, Tetranychus urticae. At a mean $20.3 \mathrm{C}, \mathrm{r}_{\mathrm{m}}$ values were 0.183 and 0.219 for $M$. occidentalis and $P$. persimilis, respectively, and 0.143 for $T$. urticae. It is difficult to compare directly the data from the present study with those of Laing, as his studies were conducted in growth chambers pro- 
grammed to provide temperatures which varied from 28.3 to $15.0 \mathrm{C}$, and the present study was conducted with constant temperatures only. Scolothrips sexmaculatus had an $\mathrm{r}_{\mathrm{m}}$ of only 0.155 at $23.9 \mathrm{C}$, and was unable to hatch at a constant $18.3 \mathrm{C}$ after 28 days of incubation (Table 3). However, eggs of S. sexmaculatus may have hatched in less than 28 days if the temperature had been programmed to exceed $18.3 \mathrm{C}$ for about $13 \mathrm{hr}$ per day, as in Laing's work. Laing's experiments and the present study indicate that, at lower temperatures, populations of the two phytoseiid predators and the tetranychid prey would each have a higher rate of population increase than would $S$. sexmaculatus. However, as discussed by McMurtry and Johnson (1966), Huffaker and Flaherty (1966), and Huffaker et al. (1970), the evaluation of a predator's efficacy should not be based solely on a comparison of intrinsic rates of natural increase for predator and prey. Among other considerations, the reduction in prey numbers caused by predation must be incorporated in the prey $r_{m}$ value. Such a procedure results in a net $r_{m}$ for the prey, and offers better comparisons of respective predator-prey population increases in a given environment.

\section{Survival at Critical Periods of Prey Availability}

No Prey or Water Provided. Fleschner (1950) stated that the most critical period in the life cycle of a predator is that time between eclosion and the first feeding, particularly at low prey densities. First-stage larvae of S. sexmaculatus survived 14.9 (range: 9-18) $\mathrm{hr}$ without food or water. Although perhaps not as critical, the survival times after 1st-stage larval molt and imaginal molt were 23.4 (range: $15-33$ ) and 25.8 (range: 18-33) hr, respectively. At the $\mathrm{P}=0.01$ level, there was no significant difference between survival times of newly molted 2nd-stage larvae and those of newly molted females, although both times were significantly different from that of 1st-stage larvae.

\section{Minimum Prey Necessary to Support Complete Immature Development}

The prey consumption by different stages of $S$. sexmaculatus was determined during the temperature studies. Those experiments provided information about responses to excess prey. The food requirements, or minimum number of prey kills necessary to support survival, are also important, especially when prey density is low. Therefore, the food requirements for larvae of $S$. sexmaculatus were determined, using two methods. The first method (I) was to limit the total numbers of mite eggs to treatment levels of $4,6,8,10,15,20$, or 25. The second method (II) was to provide prey at treatment levels of 1 , 2 , or 3 mite eggs per $24 \mathrm{hr}$ for as long as the immature thrips fed.

Prior to initiating experiments with Method I, a pilot test indicated that nine eggs were sufficient to obtain $100 \%$ survival through the 1st-stage larval molt. If more than nine eggs were provided, the excess eggs were usually killed, whether consumed or not. Consequently, in experiments utilizing 10 or more eggs, only eight were made available to 1st-stage larvae, with the balance going to the 2nd larval stage.

With Method I, at least six mite eggs were required for successful completion of the 1st larval stage, although at this level of prey provision only eight of 30 larvae molted to the 2nd larval stage. When the number of prey eggs was increased to eight, all but two 1st-stage larvae molted to the 2 nd stage. A minimum of 20 mite eggs was necessary to complete development through the 2 nd larval stage, although only eight larvae molted to prepupae at this prey level. Seven of these prepupae reached adulthood, and all were males (Tables 11 and 
TABLE 11

DEVELOPMENTAL TIME FOR EACH LARVAL STAGE OF S. SEXMACULATUS WHEN PROVIDED EGGS OF T. PACIFICUS AT SEVERAL LEVELS

OF AVAILABILITY

\begin{tabular}{|c|c|c|c|c|c|c|}
\hline \multirow[b]{3}{*}{ Method } & \multirow{3}{*}{$\begin{array}{l}\text { Number } \\
\text { prey eggs } \\
\text { provided }\end{array}$} & \multirow{3}{*}{$\begin{array}{c}\text { Initial no. } \\
\text { individuals } \\
\text { of } S . \text { sexmacu- } \\
\text { latus per level } \\
\text { of prey } \\
\text { provision }\end{array}$} & \multicolumn{4}{|c|}{ Cumulative developmental time (days)/larval stage $(\overline{\mathrm{X}} \pm \mathrm{S} \overline{\mathrm{x}})$} \\
\hline & & & \multicolumn{2}{|c|}{ 1st } & \multicolumn{2}{|c|}{ 2nd } \\
\hline & & & 'Femalea & Male $^{\mathbf{a}}$ & 'Female ${ }^{a}$ & Malea $^{\mathbf{a}}$ \\
\hline \multirow[t]{3}{*}{$\mathbf{I}$} & 20 & 30 & - & $2.3 \pm 0.1 \quad(7)^{b}$ & - & $4.5 \pm 0.2$ \\
\hline & 25 & 30 & $2.4 \pm 0.1(15)^{b}$ & $2.4 \pm 0.1(10)$ & $5.3 \pm 0.1(15)^{b}$ & $4.5 \pm 0.1(10)$ \\
\hline & $85^{c}$ & 70 & $2.4 \pm 0.1$ & $2.6 \pm 0.0(31)$ & $4.5 \pm 0.1(39)$ & $4.5 \pm 0.1(31)$ \\
\hline \multirow[t]{2}{*}{ II } & $3 / 24 \mathrm{hr}$ & 30 & $2.7 \pm 0.1(10)$ & $2.4 \pm 0.4(14)$ & $9.4 \pm 0.4(10)$ & $6.3 \pm 0.3(14)$ \\
\hline & $12 / 24 \mathrm{hr}^{\mathrm{c}}$ & 30 & $2.5 \pm 0.1$ & $2.6 \pm 0.1$ & $4.6 \pm 0.1(21)$ & $4.5 \pm 0.1$ \\
\hline
\end{tabular}

Sex was determined on emergence of adults.

b Numbers in parentheses are numbers of individuals of $S$. sexmaculatus reared to imago.

c Control.

12). When thrips larvae were provided 25 mite eggs, females required a significantly longer developmental period than did males (Table 13). All male thrips reared according to Method I developed in about the same mean amount of time, despite differences in numbers of prey eggs provided. However, females reared on 25 eggs required a significantly longer developmental period than did those reared on 85 eggs.

Larvae of $S$. sexmaculatus supplied prey according to Method II were unable to complete the 1st larval stage when provided only one mite egg per $24 \mathrm{hr}$. At two eggs per $24 \mathrm{hr}, 21$ of 30 larvae molted after killing a mean 6.52 \pm 0.25 prey eggs. Larvae were unable to complete the 2nd larval stage until provided at least three eggs per $24 \mathrm{hr}$. Female larvae provided three mite eggs per $24 \mathrm{hr}$ killed more prey and required more developmental time than did male larvae with the same treatment (Tables 11 and 12). Furthermore, when the total developmental time and numbers of eggs killed were compared for females and males reared at three mite eggs per $24 \mathrm{hr}$, the differences between sexes were significant at the $1 \%$ level (Tables 13 and 14). As was true for controls for Method I, there was no

\section{TABLE 12}

NUMBER OF EGGS OF T. PACIFICUS KILLED BY EACH LARVAL STAGE OF S. SEXMACULATUS WHEN SUCH PREY WERE PROVIDED AT SEVERAL LEVELS OF AVAILABILITY

\begin{tabular}{|c|c|c|c|c|c|c|}
\hline \multirow[b]{3}{*}{ Method } & \multirow{3}{*}{$\begin{array}{l}\text { Number } \\
\text { prey eggs } \\
\text { provided }\end{array}$} & \multirow{3}{*}{$\begin{array}{l}\text { Initial no. } \\
\text { Individuals } \\
\text { of } S \text {. sexmacu- } \\
\text { latus per level } \\
\text { of prey } \\
\text { provision }\end{array}$} & \multicolumn{4}{|c|}{ No. prey eggs killed/larval stage $(\bar{X} \pm S \bar{x})$} \\
\hline & & & \multicolumn{2}{|c|}{1 st } & \multicolumn{2}{|c|}{ 2nd } \\
\hline & & & Female $^{a}$ & Male $^{\mathbf{a}}$ & Female $^{a}$ & Male $^{\mathbf{a}}$ \\
\hline \multirow[t]{3}{*}{$\mathbf{I}$} & 20 & 30 & - & $8.0 \pm 0.0 \quad(7)^{b}$ & - & $12.0 \pm 0.0$ \\
\hline & 25 & 30 & $8.0 \pm 0.0(15)^{b}$ & $8.0 \pm 0.0(10)$ & $17.0 \pm 0.0(15)^{b}$ & $17.0 \pm 0.0(10)$ \\
\hline & $85^{c}$ & 70 & $11.3 \pm 0.3(39)$ & $10.9 \pm 0.4(31)$ & $49.8 \pm 1.2(39)$ & $39.0 \pm 0.6(31)$ \\
\hline \multirow[t]{2}{*}{ II } & $3 / 24 \mathrm{hr}$ & 30 & $8.3 \pm 0.4(10)$ & $8.1 \pm 0.4(14)$ & $29.7 \pm 1.4(10)$ & $17.8 \pm 0.8(14)$ \\
\hline & $12 / 24 \mathrm{hr}^{\mathrm{c}}$ & 30 & $11.4 \pm 0.1(21)$ & $11.7 \pm 0.8$ & $51.1 \pm 1.3(21)$ & $38.1 \pm 1.7$ \\
\hline
\end{tabular}

a Sex determined on emergence of adults.

b Numbers in parentheses are number of individuals of $S$. sexmaculatus reared to imago.

c Control. 
TABLE 13

COMPARISONS OF DEVELOPMENTAL TIMES FOR MALES AND FEMALESa OF S. SEXMACULATUS WHEN NUMBERS OF EGGS OF T. PACIFICUS WERE LIMITED BY METHODS I AND II

\begin{tabular}{|c|c|c|c|c|c|}
\hline \multirow[b]{2}{*}{ Method } & \multirow[b]{2}{*}{$\begin{array}{l}\text { No. prey } \\
\text { eggs provided }\end{array}$} & \multicolumn{2}{|c|}{$\begin{array}{c}\text { Total female } \\
\text { developmental days }\end{array}$} & \multicolumn{2}{|c|}{$\begin{array}{l}\text { Total male } \\
\text { developmental days }\end{array}$} \\
\hline & & $\begin{array}{l}\text { Number of } \\
\text { individuals }\end{array}$ & Mean \pm S.E.b & $\begin{array}{l}\text { Number of } \\
\text { individuals }\end{array}$ & Mean士S.E.b, \\
\hline \multirow[t]{3}{*}{$\mathrm{I}$} & 20 & 0 & - & 7 & $7.6 \pm 0.3 \mathrm{a}$ \\
\hline & 25 & 15 & $9.4 \pm 0.5 \mathrm{~b}$ & 10 & $7.8 \pm 0.4 a^{* \star *}$ \\
\hline & $85^{d}$ & 39 & $7.4 \pm 0.1 \mathrm{a}$ & 31 & $7.4 \pm 0.1 \mathrm{a}^{\mathrm{ns}}$ \\
\hline \multirow[t]{2}{*}{ II } & $3 / 24 \mathrm{hr}$ & 10 & $14.0 \pm 0.5 \mathrm{c}$ & 14 & $9.9 \pm 0.3 \mathrm{~b} * \star \star *$ \\
\hline & $12 / 24 \mathrm{hr}^{\mathrm{d}}$ & 21 & $7.5 \pm 0.2 \mathrm{a}$ & 9 & $7.5 \pm 0.2 \mathrm{a}^{\mathrm{ns}}$ \\
\hline
\end{tabular}

a Sex was determined on emergence of adults.

b Means followed by the same letter on a vertical line are not significantly different at the 1\% level (SNK test)

c Males and females compared on a horizontal line are *** significantly different at $\mathrm{P}=0.001$; not significantly (ns) different at $P=0.05$.

d Control.

significant difference between developmental times for control males and females in Method II.

As indicated in Tables 13 and 14, in control larvae of the same sex reared according to Methods I and II there were no significant differences in either developmental time or number of eggs killed. Both methods of diet reduction caused female larvae to increase developmental time, compared to controls, and to decrease the number of mite eggs killed. However, only male larvae pro- vided three eggs per $24 \mathrm{hr}$ increased the developmental time over controls. To summarize, immatures provided a reduced diet with Method II took longer to develop and killed more eggs than did immatures of the same sex provided a reduced diet with Method I.

Methods I and II are further compared in Table 15 according to the least number of prey kills necessary per unit of developmental time $(\mathrm{N})$. The data indicate that larvae of $S$. sexmaculatus required the least number of prey kills

TABLE 14

COMPARISON OF MEAN NUMBERS OF PREY EGGS KILLED BY MALES AND FEMALES ${ }^{*}$ OF S. SEXMACULATUS WHEN NUMBERS OF EGGS OF T. PACIFICUS WERE LIMITED BY METHODS I AND II

\begin{tabular}{|c|c|c|c|c|c|}
\hline \multirow[b]{3}{*}{ Method } & \multirow[b]{3}{*}{$\begin{array}{l}\text { No. prey } \\
\text { eggs provided }\end{array}$} & \multicolumn{4}{|c|}{ Total number of eggs killed } \\
\hline & & \multicolumn{2}{|c|}{ Female } & \multicolumn{2}{|c|}{ Male } \\
\hline & & $\begin{array}{l}\text { Number of } \\
\text { individuals }\end{array}$ & Mean士S.E.b & $\begin{array}{l}\text { Number of } \\
\text { individuals }\end{array}$ & Mean \pm S.E.b,c \\
\hline \multirow[t]{3}{*}{ I } & 20 & 0 & & 7 & $20.00 \pm 0.00 \mathrm{a}$ \\
\hline & 25 & 15 & $25.00 \pm 0.00 \mathrm{a}$ & 10 & $25.00 \pm 0.00 \mathrm{a}^{\mathrm{ns}}$ \\
\hline & $85^{d}$ & 39 & $60.76 \pm 1.22 \mathrm{c}$ & 31 & $49.92 \pm 0.83 \mathrm{~b}^{* \star *}$ \\
\hline \multirow[t]{2}{*}{ II } & $3 / 24 \mathrm{hr}$ & 10 & $38.10 \pm 1.42 \mathrm{~b}$ & 14 & $25.71 \pm 0.74 a^{* * *}$ \\
\hline & $12 / 24 \mathrm{hr}^{\mathrm{d}}$ & 21 & $62.38 \pm 1.34 c$ & 9 & $49.78 \pm 2.13 b^{\star \star *}$ \\
\hline
\end{tabular}

- Sex was determined on emergence of adults.

b Means followed by the same letter on a vertical line are not significantly different at the $1 \%$ level (SNK test).

c Males and females compared on a horizontal line are $* * *$ significantly different at $P=0.001 ;$ not sig. nificantly ( ${ }^{\mathrm{ns}}$ ) different at $\mathrm{P}=0.05$.

d Control. 
TABLE 15

COMPARISONS OF MEAN NUMBERS OF PREY KILLS PER LARVAL DEVELOPMENTAL TIMES (N) FOR MALE AND FEMALEa LARVAL STAGES OF S. SEXMACULATUS WHEN NUMBERS OF EGGS OF T. PACIFICUS WERE LIMITED BY METHODS I AND II

\begin{tabular}{|c|c|c|c|c|c|c|c|}
\hline \multirow[b]{3}{*}{ Method } & \multirow{3}{*}{$\begin{array}{l}\text { No. prey } \\
\text { eggs } \\
\text { provided }\end{array}$} & \multicolumn{6}{|c|}{ Mean number prey contacts/larval developmental time (hr) } \\
\hline & & \multicolumn{2}{|c|}{$\begin{array}{l}\text { 1st Larval } \\
\text { stage }\end{array}$} & \multicolumn{2}{|c|}{$\begin{array}{l}\text { 2nd Larval } \\
\text { stage }\end{array}$} & \multicolumn{2}{|c|}{$\begin{array}{c}\text { Both larval } \\
\text { stages combined }\end{array}$} \\
\hline & & Female & Male & Female & Male & Female & Male \\
\hline \multirow[t]{3}{*}{ I } & 20 & - & 0.1449 & - & 0.2272 & - & 0.1851 \\
\hline & 25 & 0.1388 & $0.1388^{b}$ & 0.2442 & 0.3373 & 0.1965 & 0.2314 \\
\hline & $85^{c}$ & 0.1961 & 0.1747 & 0.9881 & 0.8552 & 0.5657 & 0.4620 \\
\hline \multirow[t]{2}{*}{ II } & $3 / 24 \mathrm{hr}$ & $0.1281^{b}$ & 0.1406 & $0.1847^{b}$ & $0.1901^{b}$ & $0.1684^{\mathrm{b}}$ & $0.1712^{b}$ \\
\hline & $12 / 24 \mathrm{hr}^{\mathrm{c}}$ & 0.1900 & 0.1875 & 1.0138 & 0.8355 & 0.5661 & 0.4611 \\
\hline
\end{tabular}

a Sex was determined on emergence of adults.

b Smallest value for contacts/larval developmental time for each larval stage and both larval stages combined. c Control.

when prey was available only infrequently (Method II). Prey availability at low prey density probably most resembles conditions of Method II, particularly for those spider mite species that are not colonial in habit.

Prey Capture Success. Both larval stages and adult females of S. sexmaculatus were starved for $8 \mathrm{hr}$ after eclosion, and then were tested to determine prey capture success. All three instars recognized and captured every prey egg contacted (Table 16). However, both larval stages were less successful with newly hatched larvae, as both had identical capture-to-contact ratios of 1:1.07. Adult female mites were the most elusive and largest prey stages tested. First-stage larvae captured only about one-half of the adult mites contacted. Both 2nd-stage larval and female thrips were more successful, each capturing one mite for each 1.26 contacts.

Searching speed. The searching speed, or distance traveled per unit time, is an important element of prey finding, as the more distance traveled, the greater the probability of encountering prey. The mean searching speeds before and after $8 \mathrm{hr}$ of starvation were determined for recently eclosed 1st- and 2nd-stage larvae. Both larval stages traveled significantly farther after starvation (Table 17). The starvation period caused the larvae to move almost continuously, stopping only infrequently for periods of $3-5$ sec. The lack of significant differences between the poststarvation 5-min and 60-min observation data indicates that 5 min may have been a sufficient poststarvation observational period for both instars. Unstarved and starved 2nd-stage larvae traveled significantly farther than did 1st-stage larvae.

Area Effectively Searched. Determination of the area effectively searched (= area effectively traversed or area covered; sensu Nicholson, 1933) requires knowledge of the field of perception, speed of searching, total area searched, and the ratio of prey captures to prey contacts.

The field of perception (= area of perception; sensu Fleschner, 1950) for larvae of $S$. sexmaculatus was determined by observation to be the distance between the antennae. This is also true of Stethorus picipes Casey, Chrysopa carnea Stephens $(=C$. californica Coquillett), and Conwentzia hageni Banks (Fleschner, 1950). The mean field of perception for 1st- and 2nd-stage larvae was $0.015 \mathrm{~cm}$ and $0.021 \mathrm{~cm}$, respec- 


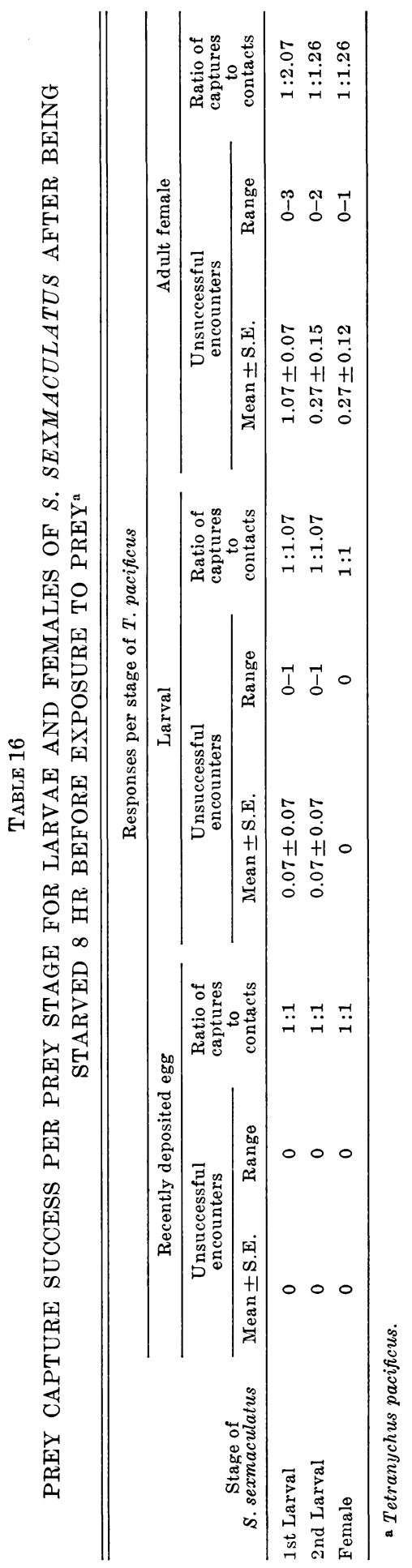

tively. The total area searched per unit time by each larval instar was calculated by multiplying the field of perception by the speed of travel shown in Table 17. Such calculations are summarized in Table 18. The area searched per unit time provides some appreciation of the potential for movement of a predator; however, it is no measure of efficiency. As discussed earlier, the various stages of prey offered differing probabilities of capture. According to Nicholson (1933), the area traversed must be modified by the success of prey capture to derive the area effectively traversed, or the area covered. When this was done for three prey stages of S. sexmaculatus, the area traversed by 1st-stage larvae was reduced by about one-half, from $5.16 \mathrm{~cm}^{2}$ when searching for mite eggs to $2.45 \mathrm{~cm}^{2}$ when searching for adult female mites. The area traversed by 2 nd-stage larvae was reduced by only about one-fourth, from $13.23 \mathrm{~cm}^{2}$ to $10.19 \mathrm{~cm}^{2}$ when searching for adult female mites.

Fleschner (1950) reported results of searching efficiency studies with $S$. picipes, C. hageni, and $C$. carnea. The prey used were adult females of $P a$ nonychus citri (McGregor). Both $S$. picipes and $C$. hageni had losses in searching efficiency when the ratio of captures to contacts was included in the calculations. The area searched by $S$. picipes declined from $99.88 \mathrm{~cm}^{2}$ (traversed) to $34.45 \mathrm{~cm}^{2}$ (covered), and that of $C$. hageni from $167.75 \mathrm{~cm}^{2}$ to 37.29 $\mathrm{cm}^{2}$. However, $C$. carnea was highly efficient, covering the same area as it traversed, $690.36 \mathrm{~cm}^{2}$. The area traversed by $S$. sexmaculatus does not compare favorably to that of these three predators. This is due to its size, which results in a very small field of perception, and to its relatively slow searching speed. However, the thrips is more efficient in capturing female mites (Table 16) than is either $S$. picipes or $C$. hageni, which had ratios of captures- 
TABLE 17

MEAN SEARCHING SPEED OF 15 EACH 1ST- AND 2ND-STAGE LARVAEa OF S. SEXMACULATUS EVALUATED BEFORE AND AFTER 8 HR OF STARVATION AT STANDARD CONDITIONS, USING T. PACIFICUS AS PREY

\begin{tabular}{|c|c|c|c|c|}
\hline \multirow[b]{3}{*}{ Test condition } & \multirow{3}{*}{$\begin{array}{l}\text { Observation } \\
\text { time (min) }\end{array}$} & \multicolumn{3}{|c|}{ Distance traveled } \\
\hline & & \multicolumn{2}{|c|}{ Centimeters/min } & \multirow[b]{2}{*}{$\mathrm{Cm} / \mathrm{hr}$} \\
\hline & & Mean \pm S.E.b & Range & \\
\hline \multicolumn{5}{|c|}{ 1st-stage larvae } \\
\hline Prestarvation.................. & 5 & $4.27 \pm 0.47 a$ & $1.00-6.90$ & 256.1 \\
\hline Poststarvation & 5 & $5.77 \pm 0.36 b$ & $2.40-7.30$ & 345.9 \\
\hline Poststarvation & 60 & $5.68 \pm 0.22 \mathrm{~b}$ & $4.00-6.45$ & 340.6 \\
\hline \multicolumn{5}{|c|}{ 2nd-stage larvae } \\
\hline Prestarvation............... & 5 & $9.65 \pm 0.49 c$ & $4.40-12.30$ & 578.7 \\
\hline Poststarvation & 5 & $10.87 \pm 0.32 \mathrm{~d}$ & $8.70-13.10$ & 649.7 \\
\hline Poststarvation & 60 & $10.67 \pm 0.32 \mathrm{~d}$ & $9.04-12.87$ & 639.6 \\
\hline
\end{tabular}

a Larvae were incubated or reared in the insectary and isolated within $1 \mathrm{hr}$ after hatching or molting. b Means followed by the same letter on a vertical line are not significantly different at the $1 \%$ level (SNK test).

to-contacts of $1: 2.9$ and $1: 4.5$, respectively (Fleschner, 1950).

During the searching capacity studies on S. picipes, C. hageni, and C. carnea, Fleschner (1950) determined that all three predators searched randomly until prey was contacted. After prey contact, the searching pattern became more tortuous and directed. Fleschner concluded from several experiments and observations that none of the predators perceived the presence of prey until actual physical contact was made. The present study included similar observations of S. sexmaculatus during the $\mathbf{1 5 0}$ hr of observing 2nd-stage larval behavior, and during the establishment of larval searching speed. As discussed previously in this paper, unstarved 2ndstage larvae on castor bean leaves were not able to perceive prey prior to actual contact. Thirty larvae, starved 8 $\mathrm{hr}$ and then each placed on a uniform arena, had no apparent searching pattern. Each larva searched with apparently random movements, covering all major portions of the arena during the 1-hr observation period.

Index of Predator Survivability at Low Prey Density. Fleschner (1950) used a formula modified from the kinetic theory of gases to calculate an approximate number of mites which would permit a predator to capture its mini-

TABLE 18

COMPARISON OF AREAS EFFECTIVELY SEARCHED BY 1ST- AND 2ND-STAGE LARVAE OF S. SEXMACULATUS, USING T. PACIFICUS AS PREY

\begin{tabular}{|c|c|c|c|c|c|}
\hline Larval stage & $\underset{\text { perception }}{\mathrm{Cm}}$ & $\begin{array}{l}\mathrm{Cm} / \mathrm{hr} \\
\text { searching } \\
\text { speed }\end{array}$ & $\begin{array}{l}\mathrm{Cm}^{2} / \mathrm{hr} \\
\text { traversed }\end{array}$ & $\begin{array}{l}\text { Ratio of captures } \\
\text { to contacts (prey } \\
\text { mite stage) }\end{array}$ & $\begin{array}{l}\mathrm{Cm}^{2} / \mathrm{hr} \\
\text { effectively } \\
\text { searched }\end{array}$ \\
\hline \multirow[t]{3}{*}{ 1st } & 0.015 & 340.10 & 5.16 & $1: 2.1$ (female) & 2.45 \\
\hline & & & & $1: 1.1$ (larva) & 4.71 \\
\hline & & & & $1: 1(\mathrm{egg})$ & 5.16 \\
\hline \multirow[t]{3}{*}{ 2nd } & 0.020 & 649.75 & 13.23 & $1: 1.3$ (female) & 10.19 \\
\hline & & & & $1: 1.1$ (larva) & 12.00 \\
\hline & & & & $1: 1$ (egg) & 13.23 \\
\hline
\end{tabular}


TABLE 19

COMPARISON OF PREYa POPULATION DENSITIES NECESSARY FOR LARVAE OF S. SEXMACULATUS TO CONTACT AND CAPTURE MINIMUM DAILY FOOD REQUIREMENTS

\begin{tabular}{|c|c|c|c|c|}
\hline $\begin{array}{l}\text { Larval } \\
\text { stage }\end{array}$ & $\begin{array}{l}\text { Stage of } \\
\text { prey mite }\end{array}$ & $\begin{array}{c}\mathrm{Cm}^{2} / \text { prey } \\
\text { individual } \\
\text { for necessary } \\
\text { contacts/hr (D) }\end{array}$ & $\begin{array}{c}\text { Ratio of } \\
\text { captures to } \\
\text { contacts ( } R \text { ) }\end{array}$ & $\begin{array}{c}\mathrm{Cm}^{2} / \text { prey } \\
\text { individual for } \\
\text { necessary captures } \\
\text { per hour }(\mathrm{S})\end{array}$ \\
\hline \multirow[t]{3}{*}{$1 \mathrm{st}$} & Egg & 70.52 & $1: 1$ & 70.52 \\
\hline & Larva & 96.52 & $1: 1.1$ & 87.75 \\
\hline & Female & 167.24 & $1: 2.1$ & 79.62 \\
\hline \multirow[t]{3}{*}{$2 \mathrm{nd}$} & Egg & 114.59 & $1: 1$ & 114.59 \\
\hline & Larva & 149.82 & $1: 1.1$ & 136.20 \\
\hline & 'Female & 246.85 & $1: 1.3$ & 189.88 \\
\hline
\end{tabular}

a Tetranychus pacificus.

mum food requirements. The formula was

$$
\mathrm{N}=\frac{\mu \gamma \quad\left(\sigma_{1}+\sigma_{2}\right)}{\mathrm{G}}
$$

where $\mathrm{N}$ represents the number of contacts per unit time, $\mu$ the searching speed of the predator, $\gamma$ the number of prey available, $\sigma_{1}$ the mean diameter of the prey, $\sigma_{2}$ the field of perception of the predator, and $G$ the total area available for movement. An assumption with this formula is randomness in the searching pattern of the predator. As discussed above, this was observed to be true for larvae of $S$. sexmaculatus in a uniform arena. The above formula does not directly provide a density of prey which should support the feeding and developmental stages of a predator. Accordingly, the formula was further modified to

$$
\mathrm{D}=\frac{\frac{1}{\mathrm{~N}}}{\mu\left(\sigma_{1}+\sigma_{2}\right)}
$$

where $\mathrm{D}$ represents the density of prey which should provide the minimum number of prey for predator survival. However, this density assumes every prey contacted was killed. As discussed earlier, this value must be further modified to account for prey not captured. This is done by the formula

$$
\mathrm{S}=\mathrm{DR}
$$

where $R$ is the number of unsuccessful contacts divided into the number of captures, D is the density of prey when all contacts represent a capture, and $\mathrm{S}$ is the adjusted density or the density of prey necessary for survival.

Minimum prey requirements were determined experimentally, using only mite eggs. Thus, to calculate minimum densities of larval and adult female mites required for survival, it was assumed that the same number of prey kills were required for the latter prey stages as for mite eggs. The mean diameter of 15 each eggs, larvae, and adult females of $T$. pacificus were $0.013 \mathrm{~cm}$, $0.023 \mathrm{~cm}$, and $0.051 \mathrm{~cm}$, respectively. The field of perception and searching speed for each larval stage of S. sexmaculatus are summarized in Table 18.

The $\mathrm{N}$-values used to calculate $\mathrm{D}$ in the present study were 0.1344 for 1 ststage larvae, 0.1874 for 2nd-stage larvae, and 0.1698 for total larval development. Each given value is an average of the lowest $\mathrm{N}$-values for males and females at each stage of larval development of $S$. sexmaculatus as listed in Table 15. Results of the calculations indicate that larvae of $S$. sexmaculatus can persist at very low densities of mite eggs, and at even lower densities of larval and female mites (Table 19). This 
was true even after allowing for capture versus contact ratios. Second-stage larvae can persist on a mite egg density less than half that necessary for 1ststage larvae.

The calculated densities of prey reported to be necessary to support $S$. picipes and $C$. carnea are one female mite per $103.88 \mathrm{~cm}^{2}$ and $152.27 \mathrm{~cm}^{2}$, respectively (Fleschner, 1950). These prey densities were obtained when the values for $\mu$ and $\sigma_{2}$ were taken from data for last-stage larvae, and $\mathrm{N}$ was computed for total development of feeding stages. If the same procedure is followed for larvae of S. sexmaculatus, the density (S) of $T$. pacificus necessary to support complete immature development becomes one prey individual per $126.46 \mathrm{~cm}^{2}, 150.33 \mathrm{~cm}^{2}$, and 209.56 $\mathrm{cm}^{2}$ for mite eggs, mite larvae, and adult female mites, respectively.

Due to a small field of perception and a relatively slow searching speed (Table 18), larvae of $S$. sexmaculatus appear to be poor prospects for survival at low prey densities. This is further evidenced by the relatively small area covered. However, the ability of such larvae to capture and kill most prey contacted, and to survive with few prey kills per larval developmental hour, would apparently permit larvae of S. sexmaculatus to survive at low prey densities, as indicated by $\mathrm{S}$ (Table 19). The index of survivability (S) does not predict larval survival in the field, but can be a useful term for evaluating the combined influence of several key attributes of predators under controlled conditions.

\section{SUMMARY}

The biology, temperature response, and food requirements of Scolothrips sexmaculatus were studied with Tetranychus pacificus as the main prey.

At $26.7 \mathrm{C}$ and $50 \%$ relative humidity, the mean duration of the life cycle from egg to adult was 8.9 (range: 7.6-10.3) days. The mean durations of the developmental stages were: egg, 7.2 days; 1 ststage larva, 2.8 days; 2nd-stage larva, 2.5 days; prepupa, 1.2 days, and pupa 2.5 days. Males and females developed in the same length of time. The mean numbers of prey eggs killed by immature females and males, respectively, were: 1st-stage larva, 11.7 and 10.4; 2nd-stage larva, 44.3 and 32.8 . The average numbers of eggs killed were significantly different between male and female larvae, being 43.2 and 56.0 , respectively.

Eggs of S. sexmaculatus are inserted into leaf tissue. Eclosion lasted a mean $7.6 \mathrm{~min}$, and 1st-stage larvae commenced feeding a mean 40.3 min after vacating the chorion. No larval preference or nompreference for any given prey stage was noted, although mite eggs were preyed on most often. Most of the photophase was spent at rest. No external sexual differences were discernible in larvae, but female prepupae and pupae were larger and more robust than male prepupae and pupae.

Imaginal molts required a mean 9.1 min, and the newly eclosed adult commenced feeding after a mean $92.7 \mathrm{~min}$. The characteristic three spots on each wing were visible within a mean 114.7 min, and other body areas darkened within 36-48 hr. Mating occurred within 5-10 hr after female eclosion, and required a mean 11.9 min.

Mating was unnecessary to induce oviposition, which usually commenced on the 1st imaginal day. Unmated females produced only male progeny. Thus, S. sexmaculatus is a facultatively arrhenotokous species. Oviposition usually took place in interveinal tissue, and required a mean 7.3 min per egg. $\Lambda$ dult females had no evident prey-stage preferences or nonpreferences. Most of the photophase was spent at rest. 
Both larval and adult thrips are behaviorally well adapted to feeding on tetranychids which produce copious webbing. Thigmotaxes were shown by all instars. Cannibalism did not occur until prey became scarce, even at high thrips population densities.

The lower thermal limit for incubation probably was between 18.3 and $23.9 \mathrm{C}$. The lower thermal limit for larval development was between 12.8 and 18.3 C. Temperatures above the lower limits induced nearly linear increases in developmental rates. The number of prey killed by larvae had no such relationship.

The lower thermal limit for mating was between 12.8 and $18.3 \mathrm{C}$. The lower thermal limit was not established for oviposition, but it did take place at $12.8 \mathrm{C}$. The lower thermal limit for production of female progeny was probably between 12.8 and $18.3 \mathrm{C}$. At 23.9 to 40.6 $\mathrm{C}$, adult female thrips produced more than a mean of 200 eggs during their lifetime. In the reproductive period, from 6.2 to 7.2 mite eggs were killed for each thrips egg produced. At 29.4 to $40.6 \mathrm{C}$, females killed more than a mean 1,700 mite eggs during their lifetime.

Longevity of adult females was inversely related to temperature and generally followed the curve of physiological longevity. Production of progeny peaked at $29.4 \mathrm{C}$, although the highest percentage of female progeny occurred at $23.9 \mathrm{C}$. The mean repro- ductive period was inversely related to temperature.

Life tables were prepared for each temperature, and the intrinsic rate of natural increase was used as a bioclimatic index. As reflected by $\mathrm{r}_{\mathrm{m}}$, S. sexmaculatus populations can persist and increase in numbers between 23.9 and $40.6 \mathrm{C}$. The optimal temperature as related to $r_{m}$ was not determined.

Males of $S$. sexmaculatus were studied at $29.4 \mathrm{C}$. They killed only about one-fourth as many prey eggs daily as did females at $29.4 \mathrm{C}$, but lived about one-third longer.

Minima of 25 and 20 prey eggs are required for development of males and females, respectively. Both sexes extended their developmental period significantly when provided only two or three mite eggs per day. The minimum number of prey kills per larval developmental hour was obtained with larvae reared on three eggs per day.

When searching for eggs of $T$. $p a$ cificus, 1st- and 2nd-stage larvae of $S$. sexmaculatus can effectively cover a rather small area, $5.16 \mathrm{~cm}^{2}$ and 13.23 $\mathrm{cm}^{2}$ per hr, respectively. However, when searching ability and minimum prey kills per hour of larval developmental time are combined, S. sexmaculatus is a very efficient larval predator at low prey densities, being able to survive on one mite egg per $126.52 \mathrm{~cm}^{2}$, or on one adult female mite per $209.69 \mathrm{~cm}^{2}$. 


\section{LITERATURE CITED}

ANDrewnRthi, H. G. and L. C. Birch

1954. The distribution and abundance of animals. Univ. of Chicago Press, Chicago. $782 \mathrm{pp}$.

BAILEy, S. F.

1939. The six-spotted thrips, Scolothrips sexmaculatus (Perg.). J. Econ. Entomol. 32:43-7.

1957. The thrips of California. Part I: Suborder Terebrantia. Bull. Calif. Ins. Surv. 4:143220.

BARTlett, B. R. and G. KATZ

1969. Inflated plastic bags as cages for insects on potted plants. J. Econ. Entomol. 62:524-5.

BEACH, A. M.

1896. Contributions to a knowledge of the thripidae of Iowa. Proc. Iowa Acad. Sci. 3:214-28.

BIRCH, L. C.

1948. The intrinsic rate of natural increase of an insect population. J. Anim. Ecol. 17:15-26.

Bursell, E.

1964. Environmental aspects: Temperature. In: Rockstein, M. (ed.). The Physiology of Insecta. Academic Press. 1:283-361.

Chapman, R. F.

1969. The Insects: Structure and Function. American Elsevier Publishing Company, Inc. New York. 819 pp.

Clark, A. M. and M. Rockstein

1964. Aging in insects. In: Rockstein, M. (ed.). The Physiology of Insecta. Academic Press. $1: 230-71$.

DEEver, E. S.

1947. Life tables for natural populations of animals. Quart. Rev. Biol. 22:283-314.

DufFy, J. C.

1892. Transformations of a carabid (Plochionus timidus), and observations on a coccinellid enemy of the red spider. Incl. footnote re-describing Thrips 6-maculata. Acad. Sci. St. Louis, Trans. 5:533-42.

Fleschiner, C. A.

1950. Studies on searching capacity of the larvae of three predators of the citrus red mite. Hilgardia 20:233-65.

1958. Natural enemies of tetranychid mites on citrus and avocado in southern California. Proc. 10th Intern. Congr. Ent. (Montreal) (1956) 4:627-31.

Garman, P.

1924. The European red mite (Paratetranychus pilosus C. and F.) in Connecticut apple orchards. Conn. Agr. Exp. Sta. Bull. 252:103-25.

Garman, P. and J. F. Townsend

1938. The European red mite and its control. Conn. Agr. Exp. Sta. Bull. 418:1-34.

Hinds, W. E.

1902. Monograph of Thysanoptera of North America. Proc. U. S. National Mus. 26:157-8.

HOOD, J. D. and G. W. HERRICK

1926. A list of the insects of New York. Thysanoptera. Mem. Cornell Univ. Agr. Exp. Sta., 101. $68 \mathrm{pp}$.

Huffaker, C.B. and D. L. Flaherty

1966. Potential of biological control of two-spotted spider mites on strawberries in California. J. Econ. Entomol. 59:786-92.

Huffaker, C. B., M. vaN dE VRIE and J. A. McMurtry

1970. The ecology of tetranychid mites and their natural enemies: A review. II. Tetranychid populations and their possible control by predators: An evaluation. Hilgardia 40: $391-458$.

LAING, J. E.

1968. Life history and life table of Phytoseiulus persimilis Athias-Henriot. Acarologia 10: 578-88.

1969a. Life history and life table of Tetranychus urticae Koch. Acarologia 11:33-42.

$1969 \mathrm{~b}$. The life history and life table of Metaseiulus occidentalis (Nesbitt). Ann. Entomol. Soc. Am. 62:978-82. 
Lamiman, J. F.

1935. The Pacific mite, Tetranychus pacificus McGregor in California. J. Econ. Entomol. 28:900-3.

LEIGH, T. F.

1963. Considerations of distribution, abundance, and control of acarine pests of cotton. In: Advances in Acarology, Vol. 1. Cornell Univ. Press. Ithaca, New York, pp. 14-20.

Lincoln, C., F. J. Williams and G. Barnes

1953. Importance of a thrips in red spider control. J. Econ. Entomol. 46:899-900.

LORD, F. T.

1949. The influence of spray programs on the fauna of apple orchards in Nova Scotia. III. Mites and their predators. Can. Entomol. 81:202-30.

McBeth, C. W., A. L. TAylor and A. L. SMith

1941. Note on staining nematodes in root tissue. Proc. Helminth. Soc. Wash. 8:26.

McGREGor, E. A.

1914. Red spider control. J. Econ. Entomol. 7:324-36.

MCGregor, E. A. and F. L. McDonough

1917. The red spider on cotton. U. S. Dept. Agr. Bull. 416:1-72.

McMurtry, J. A. and H. G. Johnson

1966. An ecological study of the spider mite Oligonychus punicae (Hirst) and its natural enemies. Hilgardia 37:363-402.

McMurtry, J. A., C. B. Huffaker and M. van de Vrie

1970. Ecology of tetranychid mites and their natural enemies: A review. I. Tetranychid enemies: Their biological characters and the impact of spray practices. Hilgardia 40:331-90.

MESSEnger, P. S.

1964. Use of life tables in a bioclimatic study of an experimental aphid-braconid wasp host-parasite system. Ecology 45:119-31.

Michelbacher, A. E.

1959. Spider mites on walnut in northern California. J. Econ. Entomol. 45:936-9.

Michelbacher, A. E., W. W. Middlekauff and O. G. Bacon

1952. Mites on melons in northern California. J. Econ. Entomol. 45:365-70.

MORI, H.

1967. A review of biology on spider mites and their predators in Japan. Mushi 40:47-65.

MUMA, M. H.

1955. Factors contributing to the natural control of citrus insects and mites in Florida. J. Econ. Entomol. 48:432-8.

1958. Predators and parasites of citrus mites in Florida. Proc. 10th Internat. Congr. Ent. (Montreal) (1956). 4:633-47.

NEwCOMER, E. J. and M. A. YoTHERS

1929. Biology of the European red mite in the Pacific north-west. Bull. U. S. Dept. Agr. 89. $69 \mathrm{pp}$.

Nicholson, A. J.

1933. The balance of animal populations. J. Anim. Ecol. Sup. 2:132-78.

OATMAN, E. R.

1970. Integration of Phytoseiulus persimilis with native predators for control of the twospotted mite on rhubarb. J. Econ. Entomol. 63:1177-80.

OAtman, E. R. and J. A. McMurtry

1966. Biological control of the two-spotted spider mite on strawberry in southern California. J. Econ. Entomol. 59:433-9.

OAtman, E. R., J. A. McMurtry, H. H. Shorey, and V. Voth

1967. Studies on integrating Phytoseiulus pcrsimilis releases, chemical applications, cultural manipulations, and natural predation for control of the two-spotted spider mite on strawberry in southern California. J. Econ. Entomol. 60:1344-51.

OAtman, E. R. and V. Voth

1972. An ecological study of the two-spotted spider mite on strawberry in southern California. Environ. Entomol. 1:34-9.

Pergande, $T$.

1882. Habits of thrips. Psyche 3:381. 
Platner, G. R., G. T. Scriven, and C. E. Braniger

1973. Modification of a compact refrigerator for bio-ecological studies under controlled physical parameters. Environ. Entomol. 2:1118-20.

Priesner, $\mathrm{H}$.

1950. Studies on the genus Scolothrips. Bull. Soc. Fouad Ier Entomol. 34:39-68.

QUAYle, H. J.

1912. Red spiders and mites of citrus trees. Calif. Agr. Exp. Sta. Bull. 234:484-530.

RICE, R. E. and R. A. Jones

1972. Experimental miticides on European red and Pacific mites. Calif. Agr. 26:12-13.

Scriven, G. T. and J. A. McMurTry

1971. Quantitative production and processing of tetranychid mites for large-scale testing or predator production. J. Econ. Entomol. 64:1255-7.

SoKAL, R. R. and F. J. RoHLF

1969. Biometry: The Principles and Practice of Statistics in Biological Research. W. H. Freeman and Company. San Francisco. $776 \mathrm{pp}$.

STANNARD, L. J.

1968. The thrips, or Thysanoptera, of Illinois. Bull. Illinois Nat. Hist. Surv. 29:215-552.

VAN DEN BOSCH, R. and K. S. HAGEN

1966. Predaceous and parasitic arthropods in California cotton fields. Calif. Agr. Exp. Sta. Bull. 820:32 pp.

vaN DE VRIE, M., J. A. MCMurtry and C. B. Huffaker

1972. Ecology of tetranychid mites and their natural enemies: A review. III. Biology, ecology, and pest status, and host-plant relations of tetranychids. Hilgardia 41: 343-432.

WATson, J. R.

1918. Thysanoptera of Florida. Florida Buggist 2:67.

1923. Synopsis and catalog of the Thysanoptera of North America. Fla. Agr. Exp. Sta. Bull. 168:11, 36 .

Whiтсомв, W. H. and K. BeLL

1964. Predaceous insects, spiders, and mites of Arkansas cotton fields. Ark. Agr. Exp. Sta. Bull. 690. 84 pp. 
The journal HILGARDIA is published at irregular intervals, in volumes of about 650 to 700 pages. The number of issues per volume varies.

Single copies of any issue may be obtained free, as long as the supply lasts; please request by volume and issue number from:

\section{PUBLICATIONS \\ UNIVERSITY OF CALIFORNIA \\ DIVISION OF AGRICULTURAL SCIENCES}

1422 South 10th Street

Richmond, California 94804 
The lower thermal limit for incubation was between 18.3 and 23.9 C; for larval development, 12.8 and $18.3 \mathrm{C}$; for mating, 12.8 and 18.3 $\mathrm{C}$; and for production of female progeny, 12.8 and 18.3 C.

At 23.9 to $40.6 \mathrm{C}$, adult female thrips produced more than a mean 200 eggs during their lifetime. During the reproductive period, a mean 6.2 to 7.2 mite eggs were killed for each thrips egg laid. At 29.4 to $40.6 \mathrm{C}$, female thrips killed more than a mean 1,700 mite eggs during their lifetime.

Longevity of adult females was inversely related to temperature. Production of total progeny was highest at 29.4 C, although the highest percentage of female progeny occurred at $23.9 \mathrm{C}$.

Life tables were prepared from data collected at four temperatures, and intrinsic rates of natural increase were calculated therefrom. The $r_{m}$ values for $S$. sexmaculatus were $0.155,0.232,0.304$, and 0.360 at $23.9,29.4,35.0$, and $40.6 \mathrm{C}$, respectively.

Minimums of 20 and 25 prey eggs were required for development of males and females, respectively. Mean developmental periods of both sexes were increased significantly when larvae were provided only two or three mite eggs per day.

First- and 2nd-stage larvae of $S$. sexmaculatus effectively searched $2.45 \mathrm{~cm}^{2}$ and $10.19 \mathrm{~cm}^{2}$ per $\mathrm{hr}$, respectively. Densities of one mite egg per $70.52 \mathrm{~cm}^{2}$ and $114.59 \mathrm{~cm}^{2}$ were required for development of 1st- and 2nd-stage larvae, respectively. 